\title{
KIRVUN LAULUSEURA JA \\ EUROOPPALAINEN LAULUJUHLA-AATE 1890-LUVUN LOPULLA
}

Kansanvalistusseuran järjestämät laulu- ja soittojuhlat olivat ensimmäisiä laajamuotoisesti organisoituja musiikkitapahtumia Suomessa. Ne olivat myös ensimmäisiä massatapahtumia sanan varsinaisessa merkityksessä, sillä alusta alkaen juhlille osallistui satoja esiintyjiä yleisömäärän noustessa useisiin tuhansiin. Ensimmäinen yleinen laulujuhla Jyväskylässä vuonna 1884 onnistui hyvin, ja seuraavaa alettiin suunnitella suuren innostuksen vallassa. Juhlia oli tarkoitus järjestää kolmen vuoden välein Kansanvalistusseuran juhlaistuntojen yhteydessä, mutta niiden järjestämisestä syntyi kova kilpailu eri kaupunkien välillä. Tästä johtuen etenkin 189o-luvusta tuli varsinainen laulujuhlien vuosikymmen Suomessa. Juhlia pidettiin lähes vuosittain järjestelyvastuun siirtyessä vuoron perään kaupungista toiseen. (Inkilä 1960: 216-220; Smeds \& Mäkinen 1984: 11-16, 29-36; Kurkela 2009: 70.)

Vaikka valtakunnalliset laulu- ja soittojuhlat järjestettiin poikkeuksetta kaupungeissa, niillä oli merkittävä vaikutus musiikkielämään myös kaupunkien ulkopuolella. Samaan aikaan tapahtuneen joukkojärjestäytymisen läpimurron kanssa musiikkijuhlat edistivät voimakkaasti laulukuorojen ja soittokuntien leviämistä kaikkialle maahan. Festivaali-innostus ilmeni myös pienempinä juhlina, joita maakuntien nuorisoseurat, raittiusyhdistykset ja muut järjestöt organisoivat eri puolilla Suomea. Paikallisesti järjestetyt laulu- ja soittojuhlat saivat mallinsa valtakunnallisilta juhlilta, mutta olosuhteista riippuen niistä saattoi muodostua hyvinkin erilaisia ja omaperäisiä tapahtumia.

(c) SES \& Saijaleena Rantanen, Etnomusikologian vuosikirja 2014, vol. 26, ss. 68-101. 
Tässä artikkelissa laulu- ja soittojuhlien paikallistaso muodostaa lähtökohdan ilmiön laajemmalle tarkastelulle. Keskeisenä tutkimuskohteena on Karjalan nuorisoseurojen järjestämä laulu- ja soittojuhla Kirvussa ${ }^{1}$ kesäkuussa 1898. Kirvun laulujuhla ${ }^{2}$ oli ensimmäinen nuorisoseuraliikkeen järjestämä laulujuhla Suomessa, ja se sai paljon huomiota sekä paikallisissa että valtakunnallisissa sanomalehdissä. Myös nuorisoseuraliikkeen omassa Pyrkijä-lehdessä laulu- ja soittojuhlien merkityksestä käytiin vilkasta keskustelua.

Paikallisuudestaan huolimatta Kirvun juhla saavutti valtakunnallisen laulujuhlan mittasuhteet. Erityisen kiinnostavaa on, että keskeisessä roolissa juhlajärjestelyissä oli yksittäinen Kirvun lauluseura. Miten oli mahdollista, että pienen maaseutupitäjän kuoro pystyi ottamaan vastuun laulujuhlien kaltaisen tapahtuman järjestämisestä 189o-luvun lopulla? Mitä yhtäläisyyksiä ja eroja Kirvun juhlalla oli suhteessa valtakunnallisiin laulu- ja soittojuhliin? Mistä vaikutteet tulivat?

\section{Paikallinen - kansallinen - ylirajainen}

Suomalaisessa historiankirjoituksessa ja -tutkimuksessa laulujuhlia on usein tarkasteltu kansallisena tapahtumana. ${ }^{3}$ Ne eivät kuitenkaan syntyneet itsenäisesti suomalaisina innovaatioina vaan kiinteässä vuorovaikutuksessa yleiseurooppalaisen kehityksen kanssa. Tärkeässä roolissa olivat Suomen musiikkielämän keskeisten henkilöiden maahantuomat ulkomaiset ideat, jotka levisivät kaikkialle maahan. Lisäksi tunnettujen säveltäjien mukanaolo lisäsi juhlien statusta sekä musiikillisesti että ideologisesti. Heidän vaikutuksensa ulottui monin tavoin myös paikallisille laulujuhlille. Juhlajärjestelyjen, -ohjelman ja tilaisuuden rakenteen lisäksi tutkin ulkopuolisten vaikutteiden ja verkostojen merkitystä Kirvun paikallislaulujuhlan syntyyn, sisältöön ja luonteeseen. Selvää on, että

\footnotetext{
I Kirvu on entinen suomalainen kunta, joka sijaitsee Neuvostoliitolle vuonna 1944 luovutetun Karjalankannaksen läntisessä osassa. Kirvun kunta koostui kaikkiaan 46:sta kylästä. Alueen väkiluku ennen toisen maailmansodan puhkeamista vuonna 1939 oli yhteensä 8721 henkeä. Suomen tilastollinen vuosikirja 1940: 28-29.

2 Kirvun laulujuhlasta on käytetty myös nimitystä Karjalan nuorisoseurojen laulu- ja soittojuhla sekä Inkilän laulu- ja soittojuhla liittyen juhlapaikan sijaintiin.

3 Tästä poikkeuksina Kerstin Smeds (1984) ja Seppo Zetterberg (1974), jotka ovat tutkimuksissaan huomioineet myös laulu- ja soittojuhlien kansainväliset yhteydet.
} 
juhla ei olisi voinut toteutua ilman verkostoja. Vaikka Kirvun tapauksessa kyse oli paikallisesta ja myös paikallisesti järjestetystä tapahtumasta, sen taustalla vaikutti yhtä aikaa sekä kansallisia että kansallisvaltion rajat ylittäviä yhteyksiä. Menetelmällisesti valitsemani näkökulma edustaa marginaalihistorian tutkimusta konkreettisimmillaan, sillä siinä mikro- ja makrotaso on yhdistettävissä niin, että tarkastellessani yhtä paikallista laulujuhlaa, voin samalla tehdä laajempaa analyysia paitsi ilmiön suomalaisesta, myös eurooppalaisesta kehityksestä.

Suomen rajojen ulkopuolelle ulottuvien yhteyksien tarkastelussa hyödynnän ylirajaisuuden käsitettä. Vaikka ylirajaisen näkökulman soveltaminen tutkimuksessa eri tieteenaloilla on viime vuosina yleistynyt suhteellisen paljon, sille ei ole muodostunut yhtä vakiintunutta määritelmää. Oman tutkimukseni kannalta erityisen käyttökelpoinen on siirtolaisuustutkija Steven Vertovecin (2009: 3) tulkinta, jonka mukaan transnationaalinen, eli ylirajainen näkökulma kohdistuu erityisesti valtioiden rajat ylittävien ei-valtiollisten toimijoiden yhteyksiin sekä näiden yhteyksien muotoutumiseen ja ylläpitoon liittyviin prosesseihin. Vertovecin kanssa samankaltaiseen määritelmään on päätynyt Jessica C. E. Gienow-Hecht (2009: 4-5) tutkimuksessaan mannereurooppalaisen musiikkikulttuurin transatlanttisista yhteyksistä 1850-luvulta 1920-luvulle. Hän korostaa kulttuuristen ja henkisten yhteyksien tärkeyttä Euroopan ja Pohjois-Amerikan välisissä suhteissa. Musiikki kuului niin sanottuihin pehmeisiin kanssakäymisen muotoihin, jotka Gienow-Hechtin mukaan olivat pitkäkestoisempia kuin taloudelliset tai poliittiset yhteydet. Hän ei kuitenkaan sulje pois musiikin ympärille muodostuneiden verkostojen yhteiskunnallisia ulottuvuuksia, sillä 180o-luvulla eurooppalaisen sivistyneistön keskuudessa musiikki nähtiin kulttuurisena ilmiönä, jolla oli monia poliittisia ja sosiaalisia vaikutuksia. Erityisesti universaaliin asemaan kohonnut saksalainen taidemusiikki nähtiin tärkeänä vastapainona teollistumisen ja kansainvälisten sotien karulle todellisuudelle. (Gienow-Hecht 2009: 9-11.)

Ylikansallisen ja ylirajaisen käsitteet kyseenalaistavat metodologisen nationalismin, jossa tutkimus kiinnittyy kansallisvaltion viitekehykseen. Musiikin historian tutkimuksessa ylirajainen näkökulma luo mahdollisuuden ymmärtää monimutkaisia, monikulttuurisia ja medioituneita kanssakäymisen muotoja musiikillisessa kontekstissa 180o-luvun Euroopassa. Celia Applegate (2011: 230-231) on todennut, että 1700-luvun lopun ja 180o-luvun eurooppalainen "musiikillinen maailma" (musical world) oli kokonaisuudessaan ylirajainen tila, joka toteutui eri- 
tyisesti kaupungeista ja maasta toiseen liikkuvien muusikoiden ja heidän mukanaan levinneiden erilaisten musiikkikäytänteiden välityksellä. Tässä yhteydessä Applegate nostaa esille myös 180o-luvulla käynnistyneen kuorolaululiikkeen merkittävänä ylirajaisten verkostojen ylläpitäänä, sillä etenkin kuorotoiminnan ympärille syntyneiden musiikkifestivaalien yleistyessä harrastajakuorot liikkuivat paljon (Applegate 2011: 239). Rautatieverkon kehittyminen mahdollisti kohtuuhintaisen ja huomattavasti aikaisempaa nopeamman matkustamisen myös oman maan rajojen ulkopuolelle. Myös Suomessa järjestettyjen laulu- ja soittojuhlien kannalta rataverkko muodostui ratkaisevaksi tekijäksi, sillä tavallisesti juhlapaikoiksi valikoituivat paikkakunnat, joilla oli asema.

Paikallisten laulu- ja soittojuhlien kannalta kesä 1898 on kiinnostava tutkimuskohde, sillä Kirvun juhla ei jäänyt ainoaksi laulujuhlaksi Suomessa kyseisenä kesänä. Myös Porissa järjestettiin paikallinen laulujuhla, joka oli ensimmäinen laatuaan Satakunnassa. Kirvun ja Porin suomenkielisten laulujuhlien lisäksi samana kesänä järjestettiin vielä kaksi ruotsinkielistä laulujuhlaa, toinen Tammisaaressa ja toinen Porvoossa. Tarkentaakseni kuvaa laulujuhlien sisällöstä ja järjestämisen syistä, vertailen näiden eri tapahtumien ohjelmistoja ja rakennetta toisiinsa, tutkimuksen pääpainon pysyessä kuitenkin Kirvussa. Keskeisen tutkimusaineistoni muodostavat Kirvun lauluseurasta kirjoitettu historiikki ja siihen liittyvä arkistoaineisto sekä paikallisia laulu- ja soittojuhlia koskeva aikalaiskirjoittelu 189o-luvulla ilmestyneissä sanoma- ja aikakauslehdissä.

\section{Kirvun lauluseuran perustaminen}

180o-lukua voi perustellusti kutsua kuorolaulun vuosisadaksi Euroopassa. Siitä huolimatta, että kuorolaululla on ollut keskeinen sija myös 1900- ja 2000-lukujen musiikkikulttuurissa, ei mikään muu aikakausi ole ollut niin moninainen kuorotoiminnan muotoihin, esiintymispaikkojen vaihtuvuuteen sekä kuorolauluun liitettyihin tarkoituksiin ja päämääriin nähden kuin 180o-luku. Silloin syntyivät myös kuorotoimintaan liittyvät keskeiset instituutiot ja organisaatiot, jotka vakiinnuttivat kuorolaulun aseman osana modernisoituvaa länsimaista yhteiskuntaa. 180o-luvun kuoroliike mobilisoi valtavan määrän ihmisiä musiikilliseen toimintaan kaikkialla Euroopassa. Yksilön- ja kokoontumisvapauden lisääntyessä 
ihmiset kaikista yhteiskuntaluokista alkoivat osallistua erilaisiin uskonnollisiin, kansallisiin ja muihin yhteisöllisiin tilaisuuksiin, yhä useammin laulukuoron tai torvisoittokunnan jäsenenä. Samaan aikaan voimistuva kustannusala nuotti- ja opaskirjoineen oli tärkeässä roolissa kuoroaatteen leviämiselle. (Ahlquist 2006: 2; Applegate 2013: 3-4.)

Suomeen uudenlainen moniääninen kuorolaulu kulkeutui 181o-luvun lopulla Upsalan yliopistossa opiskelleiden turkulaisylioppilaiden välityksellä. Sen esikuvat olivat saksalaisessa liedertafel-liikkeessä, jonka keskiössä olivat laulun ja runouden ympärille kokoontuneet mieskuorot. 180o-luvun puoliväliin saakka kuorotoiminta pysyi verrattain suppean yliopistopiirin ja harvalukuisen sivistyneistön harrastuksena. Tärkeä vaikutus kuorolaulun leviämiseen myös tavallisen kansan pariin oli kansakoululaitoksen perustamisella vuonna 1866. Opettajia valmistavassa Jyväskylän seminaarissa opiskelijat saivat muiden opintojen ohella koulutuksen myös kuoron johtamiseen ja kuorotoimintaan ylipäätään. Ensimmäiset Suomeen perustetut kuorot olivat lähes poikkeuksetta mieskuoroja, mutta niiden lisäksi seminaarissa toimi alusta saakka nais- ja sekakuoro. Myös ne saivat mallinsa KeskiEuroopasta. ${ }^{4}$ Opettajien mukana kuoroharrastus alkoi nopeasti levitä, kun he seminaarista valmistuttuaan veivät kuorolaulun mukanaan uusille toimipaikoilleen ympäri maata. Myös ylioppilaat edistivät kuoroharrastuksen voimistumista monin tavoin. Kolmas keskeinen ryhmä kuorolaulun levittäjinä olivat lukkarit ja urkurit. (Ks. Pajamo 1976; Kurkela 1989; Lehtonen 1994; Häyrynen 2003; Jäppinen 2004.)

Maaseudulle perustetut kuorot olivat tavallisesti sekakuoroja, josta tuli maallisen kuorolaulun suosituin muoto. Sekakuorot edistivät myös tasa-arvoisemman ilmapiirin kehittymistä, sillä ne mahdollistivat myös naisten osallistumisen julkiseen toimintaan. Kansakoulun ohella kuoroliikkeen tärkein edistäjä oli Suomessa 188o-luvulla tapahtunut joukkojärjestäytymisen läpimurto, joka oli saanut alkunsa Manner-Euroopassa Ranskan suuren vallankumouksen jälkimainingeissa. Järjestäytymisen myötä syntyneiden yhdistysten toiminnassa musiikilla oli alusta alkaen tärkeä tehtävä sekä kasvattajana että erilaisten yhteiskunnallisten

4 Ensimmäinen tunnettu sekakuoro oli Carl Friedrich Faschin (1736-1800) vuonna 1791 perustama Berlin Singakademie, jonka jäseniksi hyväksyttiin myös naiset ja kuorolaulun harrastajat. Laulajien joukossa oli vain muutama ammattilainen huolehtimassa moniäänisen laulun sujuvuudesta. 180o-luvun alkuun tultaessa kuoron koko oli noussut yli sataan laulajaan. Kiinnostavaa on, että yksi kuoron jäsenistä oli ensimmäisen liedertafel-kuoron (1809) perustaja Carl Friedric Zelter. (Applegate 2013: 8-9.) 
ja poliittisten aatteiden välittäjänä. Keskeisessä asemassa oli kansallisuusaate ja sen edistäminen. Tavallisesti uusien yhdistysten oheen pyrittiin heti alkuvaiheessa perustamaan lauluseura. Toisinaan se sai rinnalleen myös torvisoittokunnan. Soittokunnan perustaminen oli kuitenkin haastavaa, sillä pelkästään torvien hankinta vaati huomattavan taloudellisen panoksen. Lisäksi torvisoitto edellytti nuotinlukutaitoa, mikä kuorolaulussa ei ollut välttämätöntä. (Ks. tarkemmin Kurkela 1989; Rantanen 2013b.)

Kirvun lauluseura perustettiin lokakuussa 1881. Sen alku oli hyvin tyypillinen: nuori kansakoulunopettaja Olaus Kempas asettui paikkakunnalle ja sai ajatuksen kuoron perustamisesta. Muistitiedon mukaan Kempas oli aktiivinen kansansivistyksen harrastaja ja innokas laulumies. Kuoron perustamisen syyt olivat hyvin konkreettiset. Muistelmakirjeessään seuraajalleen Nestor Huoposelle hän kirjoitti, kuinka "nuoriso, joka usein vietti ilta- ja joutohetkensä turhuudessa ja renkutuslaulujen laulamisessa, oli vietävä ihanteellisen laulun lipun juurelle - - Jumalan ylistykseksi ja isänmaan iloksi" (Kempas Huoposelle 27.5.1901, Huoponen 1901: 9). Samaan aikaan voimistuneen kansalaisjärjestäytymisen periaatteita seuraten lauluseuran tarkoitukseksi kirjattiin "herättää kansassa halua niin kirkkoveisuun puhtaampaan ja kauniimpaan harjoituksen taitoon, kuin myös muihin isänmaallis-kansallisten laulujen oppimiseen" (Kirvun lauluseuran säännöt). Näin sinetöitiin myös lauluseuran ohjelmiston pääasiallinen sisältö ja teemat.

Jäseniksi kirjautui 19 miestä ja 14 naista, yhteensä 33 laulajaa. Ehtona lauluseuran jäsenyydelle oli "hyvä maine" sekä "kaunis ja taipuisa ääni". Lauluseuran sääntöjen mukaan hyvämaineinen jäsen oli sellainen, joka ei huvitellut "ainaisissa ja yleisissä tanssiseuroissa ja korttipeleissä". Henkilöt, jotka näin toimivat, julistettiin "kelpaamattomaksi edistämään laulun pyhää asiaa". Siveellinen elämäntapa oli musikaalisuuden lisäksi ehdoton vaatimus kuorotoimintaan osallistumiselle. (Kirvun lauluseuran säännöt.) Lauluseuran jäsenet valikoituivat eri yhteiskuntaluokista. Ensimmäiseen kokoonpanoon liittyi piikoja, renkejä, talollisia ja käsityöläisiä. (Huoponen 1901: 9-10.) Näin ollen kuorotoiminnassa toteutuivat hyvin konkreettisesti suomenmielisten fennomaanien tavoitteet tasaarvoisemmasta yhteiskunnasta säätyrajoja madaltamalla.

Kirvussa lauluseuran perustamisessa ei ollut kyse vain kokoontumisesta laulamaan yhdessä. Alusta lähtien lauluseura toimi yhdistyksen tavoin, mikä voi- 
misti yhteisöllisyyttä laulajien kesken. Sääntöjen laatimisen lisäksi kuoron yhdistysmäistä luonnetta voimisti viisijäsenisen johtokunnan perustaminen, jonka tehtävänä oli huolehtia lauluseuran asioista. Johtokunta valvoi muun muassa kuorolaisten aktiivisuutta harjoituksiin osallistumiseen, joita aluksi järjestettiin joka toinen sunnuntai. Seuran sääntöihin kirjattiin kohta, jonka mukaan jokaisesta ilmoittamattomasta poissaolosta oli maksettava 25 penniä sakkoa. Mikäli jäsen oli pois kolme kertaa peräkkäin, hänet erotettiin. Lisäksi jokaisen kuorolaisen oli hankittava virsikannel ja opeteltava sen avulla "nuottitiedettä". (Kirvun lauluseuran säännöt.) Aluksi jäseniltä perittiin myös jäsenmaksu. Siitä kuitenkin luovuttiin, sillä liiat vaatimukset olivat alkaneet verottaa jäsenistöä. Samasta syystä myös johtokunta lakkautettiin. Jatkossa laulukunta sai itse tehdä päätökset toimintaansa koskien. Myös musiikin teoriaopinnoista tuli vapaaehtoisia. (Huoponen 1901: 15-16.)

Yhdistyksen perustaminen ainoastaan musiikin ympärille oli Suomessa suhteellisen harvinaista, muttei tavatonta. Muualla Euroopassa musiikkiyhdistykset toimikuntineen, sääntöineen ja jäsenluetteloineen olivat yleisiä (Applegate 2013: 5-7). Kirvun lauluseura on esimerkki tilanteesta, jossa soittokunta tai kuoro toimivat pontimena järjestöelämän muodostumiselle kotipaikkakunnallaan. Ennen lauluseuraa Kirvussa toimi ainoastaan vuonna 1875 perustettu maanviljelysseura, jonka jäsenistö koostui lähinnä sivistyneistöstä. (Sutinen 1971: 4.) Tavallisempaa kuitenkin oli, että ensin perustettiin yhdistys ja sen yhteyteen laulu- ja soittokunta. Useimmiten soittokuntien ja kuorojen toiminta perustui vapaaehtoiseen yhteisöllisyyteen ilman erityisiä sääntöjä.

\section{Toiminnan vakiintuminen}

Alkuvaiheessa Kirvun lauluseuran toiminta kärsi johtajan jatkuvasta vaihtumisesta. Nestor Huoposen (1861-1916) saapuessa paikkakunnalle vuonna 1885, kuorolla oli ollut jo neljä eri johtajaa. Aloittaessaan tehtävänsä Kirvun uutena lukkarina Huoponen otti samalla vastuun kuoron toiminnasta. Se kävi häneltä luonnostaan, sillä Huoponen oli perustanut ja johtanut kuoroja jo edellisillä toimipaikoillaan Mäntyharjussa ja Sortavalassa. Hän oli muun muassa johtanut Mäntyharjun kuoron voittoon Kansanvalistusseuran ensimmäisillä laulu- ja soittojuhlilla Jyväsky- 
lässä. Huoponen oli myös kansallisuusaatteen vankka kannattaja ja hyvin kiinnostunut yhteiskunnallisista asioista. Hän oli valmistunut Turun lukkarikoulusta vuonna 1879 ja ennen saapumistaan Kirvuun toiminut lukkari-urkurina Mäntyharjun ja Sortavalan lisäksi Turun tuomiokirkkoseurakunnassa. Kirvussa Huoponen saavutti nopeasti pitäjäläisten luottamuksen. Jo vuonna 1886 hänet valittiin Kirvun kuntakokouksen esimieheksi. Hän hoiti tehtävää vuoteen 1891 saakka. Lisäksi Huoponen toimi Kirvun palovakuutusyhtiön toimitusjohtajana, postinhoitajana sekä kirjallisuusseurojen ja vakuutusyhtiöiden esimiehenä. Hän oli aktiivisesti mukana myös lukkari-urkurien ammattikunnan toiminnassa organisoimalla tapaamisia ja hoitaen Suomen Lukkariköörin sihteerin sekä sanomalehtikirjeenvaihtajan tehtäviä. (Jyrkinen \& al. 1993: 136-137.) Aktiivisuutensa vuoksi hänellä oli monia tärkeitä verkostoja musiikkielämän keskeisiin henkilöihin Suomessa.

Huoposen toiminnan myötä lauluseuran toiminta vakiintui nopeasti ja esiintymiskutsuja erilaisiin tilaisuuksiin alkoi tulla yhä enemmän. Harjoituksia pidettiin kansakoululla joka sunnuntai ja toisinaan myös arki-iltoina. Lisäksi Huoponen järjesti nuotti- ja kanteleensoiton opetusta halukkaille. Kuoron yhteyteen perustettiin mieskvartetti, joka esiintyi pienemmissä tilaisuuksissa. Kvartetin johtajana toimi kirvulainen ylioppilas, Kirvun kirkkoherran Ulrik Siegbergin poika Artur Siegberg (1862-1948), jolla oli kokemusta kuorotoiminnasta Helsingin opintojensa myötä. Kvartetin ohjelmisto koostui pääsääntöisesti ylioppilaslauluista. (Huoponen 1901: 16-19.) Johtajista ei siis Kirvussa ollut pulaa, mikä oli harvinaista vielä 188o-luvulla. Yleisin este kuorojen tai vastaavasti soittokuntien perustamiselle oli juuri osaavien johtajien puute.

Todellista innostusta harjoituksiin toi Huoposen innostunut suhtautuminen Kansanvalistusseuran laulu- ja soittojuhlia kohtaan. Hän oli vakuuttunut siitä, että laulujuhlat olivat "onnistunut keino herättämään ihmisiä tajuamaan laulun ja soiton jalostavaa vaikutusta" (Huoponen 1901: 29). Suhteellisen lyhyen harjoittelun jälkeen hän päätti ilmoittaa kuoron Jyväskylän toisille laulu- ja soittojuhlille 1887 ja heti perään Viipuriin 1889, jossa Huoponen toimi myös Suomen Lukkariköörin johtajana. Samalla innostus kuorotoimintaan kohosi entisestään, jonka seurauksena kuorolaisten lukumäärä kasvoi jatkuvasti. Viipurin juhlassa Kirvun lauluseuraan kuului jo 70 laulajaa. Suuren kokonsa vuoksi siitä pystyttiin muodostamaan kolme eri osastoa - sekaääninen, miesääninen ja naisääninen - joissa kaikissa myös kilpailtiin. Tässä vaiheessa harjoituksia alettiin pitää niin 
usein kuin mahdollista. Toisinaan harjoiteltiin jopa yli yön. Ahkeruus kannatti, sillä Viipurissa kaikki kolme osastoa voittivat ensimmäisen palkinnon II-sarjassa. Myös Jyväskylän juhlassa 1887 sekakuoron lisäksi mukana oli mieskvartetti, joista molemmat sijoittuivat kilpailun II-sarjassa toiseksi. Mieskuoroa kummassakin tapahtumassa johti Siegberg, joka oli Viipurin juhlaan tultaessa kartuttanut kokemustaan kuoronjohtajana myös Savo-Karjalaisen Osakunnan mieskuoron, Helsingin Suomalaisen Seuran sekakuoron ja Hämeenlinnan naiskuoron johtajana. Kuorolaisten matkarahat kerättiin järjestämällä arpajaisia, laulajaisia ja iltamia. Myös Kirvun kunta ja myöhemmin nuorisoseura avustivat esiintymismatkoja rahallisesti. Esiintymismatkoilla ja niihin valmistautumisella oli valtava yhteisöllinen vaikutus kuorolaisten kesken. Niiden aikana luotiin myös muita tuttavuuksia, vaihdettiin nuotteja ja omaksuttiin malleja erilaisten tapahtumien järjestämisestä. (Huoponen 1901: 20, 30-34; Saarnio 1901: 124; ks. myös Siikaniemi 1901: 94-105.)

Toisinaan esiintymismatkoista muodostui suoranaisia kiertueita. Esimerkiksi Jyväskylän laulujuhlan yhteydessä vuonna 1887 kuoro esiintyi laulukilpailun lisäksi myös Antreassa, Jääskessä, Lappeenrannassa, Lahdessa, Punkaharjulla, Savonlinnassa ja Mikkelissä (Ylönen 1954: 518-519). Matkan aikana annetut konsertit olivat hyvää harjoitusta kilpailua varten.

Menestyksestä huolimatta Kirvun lauluseura osallistui laulujuhlille seuraavan kerran vasta seitsemän vuoden kuluttua Sortavalassa 1896. Viipurin ja Sortavalan juhlien välisenä aikana Kansanvalistusseuran toimesta oli järjestetty neljä laulu- ja soittojuhlaa - Jyväskylässä 189o, Kuopiossa 1891, Turussa 1892 ja Vaasassa 1894 - mutta tarvittavien matkavarojen puuttuessa kuorolla ei ollut mahdollisuuksia ottaa niihin osaa. Avustuksista huolimatta välimatkat olivat pitkiä ja Kirvun kuoron koon vuoksi osallistuminen olisi tullut liian kalliiksi. Huoponen oli kuitenkin mukana sekä Kuopion että Turun juhlilla Lukkariköörin johtajan tehtävissä.

Välivuodet eivät olleet heikentäneet Kirvun lauluseuran taitoja, sillä Sortavalassa se saavutti todellisen suosion voittamalla ensimmäisen palkinnon sekakuorojen ensimmäisessä sarjassa. Lauluseura piti Sortavalassa myös kaksi erillistä konserttia. Laatokka-lehden toimittaja oli paikalla ensimmäisessä konsertissa ja kirjoitti siitä ylistävän arvion: 
Kirvun sekaköörin konserttia kuulemaan oli tiistai-iltana kerääntynyt väkeä miesseminaarin juhlasali täpösen täyteen. Konsertista toivottiin hyvää, sillä tiedettiinhän, että köörin johtaja, kanttori Huoponen, on toimessaan taitava ja kokenut mies, joka jo monessa laulujuhlassa tätä ennen on johtanut joukkonsa kauniisiin voittoihin. Eivätkä tälläkään kertaa toiveet pettäneet. - - Tulokset olivat oivalliset. Kööri seurasi täydellä tarkkuudella johtajansa viittauksia ja yhteislaulu oli aivan moitteeton. Nyansit suoritettiin erittäin huolellisesti ja ne todistivat selvästi, että laulujen harjoittamiseen oli pantu tarpeeksi tunnollista työtä. Yleisö osoittikin tajuavansa nämä köörin hyvät ominaisuudet ja antoikin niille tunnustuksensa. Jokaisen laulun jälkeen kaikuivat äänekkäät suosionosoitukset. Taputettiin käsiä, tömistettiin jalkoja ja huudettiin 'hyvä', 'hyvä'! Useat oli ne laulut, joita piti laulaa uudelleen. - - Se tapa, millä kööri lauloi mitä vienoimman, mehevimmän pianissimon ja siitä asteittain paisutti ääntä täyteen fortissimoon, oli kerrassaan erinomaisen hyvä ja teki mainion vaikutuksen. (Laatokka 18.6.1896.)

Kuten lehtiarviokin osoittaa, kuorolle ja erityisesti sen johtajalle oli tässä vaiheessa kertynyt jo runsaasti mainetta ja kokemusta. Niinpä, kun seuraavana kesänä 1897 Itä-Karjalan nuorisoseuran kesäjuhlilla Hiitolassa tehtiin päätös järjestää laulu- ja soittojuhla seuraavan kesän nuorisojuhlan yhteydessä, oli selvää, että taiteelliseen vastuuseen ehdotettiin Kirvun lauluseuraa. (Pyrkijä 7/1897; Wuoksi 28.6.1898.) Hiitolan kokouksen aikaan Kirvussa toimi myös paikallinen nuorisoseura, joka oli perustettu kolme vuotta aikaisemmin 1894. Kiinnostavaa onkin, miksi nuorisoseuraa ei ehdotettu päävastuuseen juhlajärjestelyistä lauluseuran sijaan - olihan kyseessä nuorisoseuraliikkeen maakunnallisen keskusseuran järjestämä tapahtuma. Valintaa voi perustella kolmella keskeisellä syyllä. Ensinnäkin lauluseura oli siihen mennessä ollut toiminnassa jo 16 vuotta, joiden aikana sille oli kertynyt kokemusta erilaisten tapahtumien järjestämisestä. Toiseksi kuorolla oli käytännön kokemusta myös valtakunnallisista laulujuhlista, mikä luonnollisesti oli tärkeää. Kolmanneksi Kirvun nuorisoseura oli lähes sama asia kuin Kirvun lauluseura: nuorisoseuran johtajana toimi Huoponen ja seuran jäsenistö rakentui paljolti kuorolaisista, joita oli kesään 1898 tultaessa kertynyt jopa 120 . Sanomalehdissä nuorisoseurasta käytettiinkin usein nimitystä Kirvun laulu- ja nuorisoseura. Nuorisoseuran lisäksi Kirvussa toimi 189o-luvun lopussa myös raittiusseura, ompeluseura, maamiesseura (ent. maanviljelysseura), voimistelu- 
seura sekä työväenyhdistys, joista monessa Huoponen myös toimi aktiivisesti (Jyrkinen \& al. 1993: 136-137).

\section{Kirvun laulujuhla paikallisena ilmiönä}

189o-luvun aikana nuorisoseuraliike kohosi suosituimmaksi järjestäytymisen muodoksi Suomessa. Samalla musiikin harrastusta alettiin entistä enemmän korostaa nuorisoseurojen keskeisenä toimintamuotona. Musiikillisesti näyttävin uutuus oli paikalliset laulu- ja soittojuhlat, joiden järjestämisestä alettiin keskustella seurojen kokouksissa vuosikymmenen puolivälissä. Paikallisia laulujuhlia oli järjestetty aikaisemmin Kansanvalistusseuran haaraosastojen toimesta, mutta muuhun järjestöelämään innostus ei ollut vielä levinnyt lukuun ottamatta yksittäisten kuorojen ja soittokuntien vierailua Kansanvalistusseuran järjestämillä valtakunnallisilla juhlilla. Nuorisoseuraliikkeen näkökulmasta keskeisin tavoite laulujuhlien järjestämiselle oli kuorojen ja torvisoittokuntien lukumäärän kasvattaminen paikallistasolla. Vaikka erilaiset musiikkipitoiset tilaisuudet olivat 189o-luvun aikana tasaisesti lisääntyneet koko maassa, oli kuorojen ja soittokuntien lukumäärä maakunnissa vielä suhteellisen vähäinen.

Huoli kuoroharrastuksen tilasta nousi esille nuorisoseurojen ensimmäisessä yhteisessä keskustelukokouksessa Jyväskylässä kesällä 1895. Keinoksi harrastuksen kohottamiseksi ehdotettiin yksiäänisten lauluseurojen perustamista, sillä yksiääninen laulu ei vaatinut samalla tavalla musiikillista lahjakkuutta kuin moniääninen kuorolaulu. Näin kaikilla olisi mahdollisuus osallistua kuorotoimintaan. Samalla säädyttöminä pidettyjen reki- ja piirileikkilaulujen sekä harmonikansoiton kaltaiset "rikkaruohot" saataisiin kitkettyä nuorison keskuudesta. Kokouksen sihteeri kirjasi pöytäkirjaan kehotuksen, jonka mukaan nuorisoseuran paikallisosastojen oli pyrittävä perustamaan yksiäänisiä laulukuntia. (Pyrkijä 3b/1895.) Monet olivatkin ryhtyneet toimeen, sillä Pyrkijän vuosittaisessa katsauksessa nuorisoseurojen toimintaan Suomessa vuonna 1896 todettiin, että yksiäänistä laulua oli alettu harrastaa melkein kaikissa haaraosastoissa. Useissa seuroissa sen harjoittamiseen oli käytetty Kansanvalistusseuran kokoamia ja julkaisemia Yksiäänisiä lauluja -vihkoja. (Pyrkijä 2/1897.) 
Maaliskuussa 1896 Pyrkijässä kirjoitettiin Etelä-Pohjanmaan nuorisoseuran aikeista järjestää paikallinen laulu- ja soittojuhla seuraavana kesänä. Pyrkimykset eivät kuitenkaan tuottaneet tulosta vielä tässä vaiheessa. (Pyrkijä 3/1898.) Ensimmäisenä toimeen tarttuivat Karjalan nuorisoseurat Kirvun lauluseuran johdolla kesällä 1898. Nuorisoseuraliikkeen kannalta Kirvun laulu- ja soittojuhlan järjestämisajankohta oli verrattain myöhäinen siihen nähden, että sekä nuorisoseuraliike että Kansanvalistusseuran laulu- ja soittojuhlatraditio olivat jo 20-vuotiaita. Kokonsa ja rakenteensa vuoksi laulujuhlien järjestäminen vaati kuitenkin runsaasti aikaa ja erityisen hyvää organisointikykyä, minkä vuoksi tehtävä oli monelle maaseutuyhdistykselle liian haastava. Samasta syystä juhlan järjestäminen venyi myös Etelä-Pohjanmaalla (Pyrkijä 3/1898). Maakunnissa juhlajärjestelyjä rajoitti lisäksi musiikkitoiminnan vähäisyys. Onnistuakseen laulu- ja soittojuhla vaati tietyn määrän vapaaehtoisia laulu- ja soittokuntia huolehtimaan juhlan musiikkiohjelmasta.

Kirvun juhla järjestettiin juhannuksena, 24.-25. kesäkuuta. Hyvien yhteyksien vuoksi juhlapaikaksi valikoitui Inkilän juna-aseman lähellä sijainnut luonnonkenttä, jota sanomalehtien juhlaselostuksissa kehuttiin erityisen kauniiksi. Kenttä oli koristeltu lipuilla ja "kevättangoilla". Juhlapaikan kruunasi musiikkilava, jota koristi lyyra ja lavan molemmilla sivuilla Karjalan vaakunat. (Laatokka 29.6.1898.) Laatokka-lehden arvion mukaan yleisöä oli saapunut paikalle yli 6000 henkeä. Kilpailemaan oli ilmoittautunut kymmenen sekakuoroa, seitsemän mieskuoroa ja kuusi soittokuntaa, eli yhteensä noin 300 laulajaa ja 50 soittajaa. Kun mukaan laskettiin lauluseurat, jotka eivät kilpailleet, laulajien ja soittajien lukumäärä nousi yli 500:n. (Laatokka 4.7.1898.) Se oli keskimäärin yhtä paljon tai jopa enemmän kuin Kansanvalistusseuran järjestämillä valtakunnallisilla laulujuhlilla aikaisemmin lukuun ottamatta Kuopion (1891) ja Mikkelin (1897) juhlia, jolloin kilpailuihin osallistui yli 700 soittajaa ja laulajaa sekä kaksi vuotta aikaisemmin järjestettyä Sortavalan laulujuhlaa, johon osallistui ennätykselliset 967 kuoro- ja soittokuntalaista (Smeds \& Mäkinen 1894: 64). Suureen osallistujamäärään kiinnitettiin huomiota myös Pyrkijässä, jonka mukaan Kirvussa laulujuhlan "valmistukset ja varustukset olivat yhtä suurellaiset kuin tähän asti kaupungeissa pidetyissä laulu- ja soittojuhlissa, vaikka tämä olikin maalaiskunnassa" (Pyrkijä 7/1898). 
Laulu- ja soittojuhlalla oli kirvulaisten keskuudessa valtava yhteisöllinen merkitys, sillä koko pitäjä rekrytoitiin mukaan juhlajärjestelyihin. Kaikkien kynnelle kykenevien apua tarvittiin. Eniten päänvaivaa aiheutti juhlavieraiden majoituksen järjestäminen, missä turvauduttiin myös lähialueiden asukkaiden vieraanvaraisuuteen. Koska vieraat majoitettiin pääsääntöisesti kyläläisten koteihin, Inkilän alueella ei yksinkertaisesti ollut tarpeeksi tilaa kaikkien majoittamiseen. Juhlan ajaksi palkattiin myös ajureita kuljettamaan vieraita juhlapaikalle ja edelleen kaukaisempiin majapaikkoihin. Paikallisissa sanomalehdissä kyläläisiä houkuteltiin mukaan toimintaan ja kerrattiin juhlan merkitystä Kirvulle. Järjestelyt aloitettiin mahdollisimman aikaisin. Tammikuussa pidettiin jo edellisen vuoden puolella perustetun juhlatoimikunnan kokous, jossa toimikunnan puheenjohtajaksi valittiin odotetusti Huoponen. Varapuheenjohtajaksi ja kirjuriksi valittiin opettaja A. J. Vartiainen. Samassa kokouksessa perustettiin myös kahdeksan eri toimikuntaa, jotka huolehtivat kustakin juhlajärjestelyiden osa-alueesta, kuten ohjelmistosta, majoituksesta ja koristeluista. Kesään tultaessa juhlatoimikunnan koko oli noussut yli kahteensataan henkeen. Tuntuvimman avun juhlajärjestelyihin antoi Viipurin saha osakeyhtiö, joka omisti maat Inkilän aseman ympärillä. Saha lahjoitti Kirvun laulujuhlatoimikunnalle juhlapaikan käytettäväksi maksutta ja lisäksi musiikkilavaan tarvittavat materiaalit, joiden arvo oli noin 600 markkaa (Päivälehti 28.6.1898). Laulujuhlasta muodostui kirvulaisten yhteinen hanke. (Wuoksi 20.1.1898.)

Kirvun juhlalla oli monia vaikutuksia paitsi paikallisella, myös maakunnallisella tasolla. Sanomalehtien välityksellä kaikille lähiseudun laulu- ja soittokunnille lähetettiin kutsukirje sekä juhlaan että kilpailuun. Myös nuorisoseurojen ulkopuoliset musiikkiseurat toivotettiin tervetulleeksi. Omien musiikkiosastojen lisäksi juhlaan osallistuikin kuoroja ja soittokuntia myös raittiusseuroista ja työväenyhdistyksistä. (Mikkeli 1.7.1898; Wiipurin Sanomat 3.6.1898.) Laulu- ja soittojuhlien vakiinnuttua osaksi nuorisoseurojen toimintaa osallistujat olivat pääasiassa seurojen omia musiikkiosastoja, mutta etenkin alkuvaiheessa oli tavallista, että juhliin osallistui myös muita laulu- ja soittokuntia. (Särkkä 1973: 49, 81.)

Juhlatoimikunnan puolesta kuorojen ja soittokuntien osallistumista helpotettiin määräämällä laulajille ja soittajille vapaan pääsyn juhlaan sekä "vaatimattoman kortteerin" maksutta (Wuoksi 1.3.1898). Viipurista ja Sortavalasta järjestettiin myös ylimääräisiä junavuoroja Inkilään laulujuhlan aikana. Tapa oli tuttu valtakunnallisilta juhlilta. Sanomalehdissä juhlayleisöä ohjeistettiin tarkoin junien 
kulusta, jotta kaikki olisivat varmasti oikeassa junassa ja ajoissa paikalla. (Wiipurin Sanomat 3.6.1898.) Omasta kokemuksestaan Huoponen oli itse tietoinen esiintymismatkojen aiheuttamista taloudellisista haasteista yksittäisille musiikkiseuroille ja halusi edesauttaa juhlaan osallistumista kaikin mahdollisin tavoin. Kustannuksia vähentämällä myös köyhemmän kansanosan, joka valtakunnallisilla juhlilla loisti poissaolollaan, toivottiin saapuvan paikalle. Mitä ilmeisemmin tavoitteessa myös onnistuttiin, sillä sanomalehdissä huomioitiin tyytyväisyydellä, kuinka useat kilpailijat olivat "kansan syvistä riveistä lähteneitä" - vaikkakin Laatokka-lehden arvostelijan mukaan näiltä "kokonaan kansan lapsista" kootuilta kuoroilta puuttuivat vielä "ne edellytykset, joita kilpailevalta laulukunnalta vaaditaan". (Laatokka 29.6.1898.)

Sanomalehtikirjoittelussa juhlan pääasiallinen tarkoitus tehtiin lukijoille selväksi. Tavoitteena oli laulun ja soiton avulla sekä laulu- ja soittokuntien lukumäärää lisäämällä "herättää kansallistunnetta ja isänmaanrakkautta tässä kauniissa Karjalassa, laulun laajassa kotimaassa". Kirvun laulu- ja soittojuhlan ideologia kopioitiin Kansanvalistusseuran valtakunnallisilta laulujuhlilta, mutta tavoitteet kohdistettiin paikallisemmin. Samat teemat kansallistunteen herättämisestä musiikin keinoin toistuivat juhlapuheissa. Sanomalehtikirjoittelun mukaan "juuri Karjala oli se alue", missä erityisesti tarvittiin kohotusta kansallisuusaatteen edistämisessä. Kirvuun oli saapunut sanomalehtitoimittajia peräti viidestätoista eri sanomalehdestä. Myös heille oli varattu ilmainen sisäänpääsy ja majoitus. (Mikkeli 1.7.1898.) Se oli pieni korvaus toimittajien aktiivisen kirjoittelun tuomaan valtakunnalliseen julkisuusarvoon nähden.

\section{Valtakunnalliset laulujuhlat esikuvana}

Paikallisesti järjestetyt laulu- ja soittojuhlat muistuttivat hyvin paljon valtakunnallisia laulu- ja soittojuhlia. Kansanvalistusseuran laulujuhlat muodostivat mallin, jota muiden järjestöjen oli helppo seurata. Näkyvimpänä erona oli se, että paikalliset juhlat olivat lähtökohtaisesti vain yksi- tai kaksipäiväisiä. Niiden ohjelmaan eivät myöskään tavallisesti kuuluneet sävellystilaukset tai -kilpailut. Lisäksi paikallisilla juhlilla ohjelmistoa muokattiin tarpeen ja mahdollisuuksien mukaan. Kirvussa päätettiin heti alkuvaiheessa jättää laulukilpailu naiskuorojen 
sarjassa pois ohjelmasta. Päätöstä perusteltiin sillä, että niiden osanotto oli aikaisemmin ollut vähäinen myös valtakunnallisilla juhlilla. "Naisääniset" lauluseurat toivotettiin kuitenkin lämpimästi tervetulleiksi juhlaan ja myös esiintymään kilpailun ulkopuolella. (Wuoksi 1.3.1898.)

Myös torvisoittokuntien vähäisestä lukumäärästä oltiin juhlavalmisteluiden alkuvaiheessa huolestuneita. Asian edistämiseksi juhlatoimikunnan jäsenet tekivät muun muassa henkilökohtaisia vierailuja lähikuntiin joissa tiedettiin toimivan soittokunta, ja houkuttelivat niitä osallistumaan Kirvun juhlaan. Esimerkiksi Pölläkkälässä Huoponen sopi vaihtokaupasta, jossa vastineeksi Pölläkkälän sahan soittokunnan esiintymisestä Kirvussa, Kirvun kuoro esiintyisi Pölläkkälän kesäjuhlilla samana kesänä. (Huoponen 1901: 127.)

Aikaisemmin samalla viikolla järjestetyssä Satakunnan laulu- ja soittojuhlassa ohjelmaa oli kilpailijoiden puuttuessa jouduttu muuttamaan vielä enemmän. Laulu- ja soittokilpailuun oli ilmoittautunut ainoastaan kaksi sekakuoroa, yksi mieskuoro ja kaksi soittokuntaa. Vastaavasti urheilukilpailuihin osallistuminen oli vilkasta, mitä juhlaan osallistunut Oskar Merikanto syvästi paheksui. Hänen mukaansa urheilukilpailut eivät kuuluneet laulu- ja soittojuhlien ohjelmaan. Kilpailun ulkopuolella juhlaan oli osallistunut runsaastikin laulu- ja soittokuntia, mutta ilmeisesti esiintymiskokemuksen vähäisyydestä johtuen juhlan musiikkiohjelmaa oli täydennetty järjestämällä poikkeuksellisen paljon yksittäisiä tilauskonsertteja. Satakunnassa esiintyi muun muassa Ylioppilaskunnan Laulajat ja Jyväskylän seminaarin sekakuoro, jotka kumpikin konsertoivat kolmesti. Heidän lisäkseen konsertteja antoi Merikanto, sisarukset Ida ja Fanny Flodin, laulajatar Sigrid Sundgrén yhdessä pianisti Georg Schneevoigtin kanssa sekä Selin Palmgrén ja laulajatar Elise Liljeblad. Konserttien tarkemmasta sisällöstä ei sanomalehtikirjoittelun perusteella saa kattavaa kuvaa, mutta olemassa olevan tiedon mukaan niiden ohjelmistoissa oli ainakin isänmaallisia lauluja, kansanlauluja, aaria Sevillan parturista sekä verrattain paljon mannereurooppalaista klassista pianomusiikkia muun muassa Lisztilta. Juhlan kohokohta oli Satakunnan laulun ensiesitys. Laulu oli tehty varta vasten juhlaa ajatellen. Laulun sanat olivat Kustaa Killisen ja sävel Oskar Merikannon. Laulun esittivät toisen päivän juhlakonsertissa Porin kansallis- ja naiskööri sekä Rauman sekakööri Merikannon itsensä johdolla. Odotusten mukaisesti esitys sai osakseen valtavan suosion. (Päivälehti 29.6.1898.) 
Näitä muutoksia lukuun ottamatta sekä Satakunnan että Kirvun juhlaohjelman rakenne oli hyvin samankaltainen valtakunnallisten laulujuhlien kanssa. Kirvussa ensimmäisenä päivänä järjestettiin juhlalaulajais-soittajaiset, puheita, runonlausuntaa, arpajaiset sekä näytelmäkappale, toisena päivänä vuorossa oli nuorisoseurojen keskustelukokous, laulu- ja soittokilpailu kahdessa sarjassa, urheilukilpailu sekä kansanjuhla. Satakunnassa ohjelma täydentyi vielä historiallisella juhlakulkueella, joka oli kuulunut Kansanvalistusseuran laulujuhlien ohjelmistoon vuodesta 1891 lähtien. (Wuoksi 1.3.1898; Vaasan Sanomat 7.6.1898; Mikkelin Sanomat 28.6.1898.)

Laulajien ja soittajien kilpailuaktiivisuudesta johtuen Kirvun laulujuhlan musiikkiohjelmisto muistutti enemmän perinteistä laulujuhlaohjelmistoa kuin Satakunnassa. Musiikki oli valittu aikaisemmin painetuista Kansanvalistusseuran sekä ylioppilaiden laulu- ja soittovihkoista. Ohjelmassa oli myös yksiäänistä laulua. Paikallisilla juhlilla musiikkiohjelma pyrittiin tavallisesti kauttaaltaan pitämään mahdollisimman kansantajuisena. Satakunnan ohjelmisto vaikutti siihen nähden poikkeuksellisen taiteelliselta. Epätavallista oli myös Satakunnan laulun tilaaminen juhlaa varten. Tapa oli yleinen valtakunnallisilla juhlilla, mutta ei tavallisesti kuulunut paikallisten laulujuhlien luonteeseen. Nuorisoseuran laulu- ja soittojuhlien tärkeimpänä ajatuksena oli soiton ja laulun harrastuksen edistäminen sekä "kansallisen herätyksen ja innostuksen sekä yhteishengen ja toiminnan herättäminen". Musiikillisen kyvyn kohottaminen tuli vasta toisena. (Vaasan Sanomat 2.12.1898.) Helpomman ohjelmiston avulla haluttiin madaltaa paikallisten laulu- ja soittokuntien osallistumiskynnystä.

\section{Juhlan kulku}

Kirvun laulujuhla alkoi klo 12 opettaja Vartiaisen tervehdyspuheella laulajille ja soittajille. Puheen jälkeen pidettiin laulu- ja soittoharjoitukset. Torvisoittoa juhlassa johti Huoposen ystävä ja kollega, viipurilainen kanttori Emil Sivori, miesäänistä laulua Arthur Siegberg, joka toimi laulujuhlan aikaan Ylioppilaskunnan Laulajien johtajana. Sekaäänistä laulua johti Huoponen itse. Kaikki kolme kuuluivat myös laulu- ja soittokilpailun tuomaristoon. 
Harjoitusten jälkeen oli vuorossa konsertti, joka aloitettiin virrellä Jo joutui armas aika. Se laulettiin sekaäänisesti torvien säestyksellä. Juhlaohjelmassa vuorottelivat puheet ja musiikkiesitykset. Sanomalehtikirjoittelun mukaan sekakuorot lauloivat ainakin Gluckin Juhlalaulun, Kreutzerin Paimenen sunnuntailaulun, Palmerin Rauha vaan, Sivorin Kehtolaulun, Bellmanin Neitsyen sekä Porilaisten marssin ja Maamme-laulun torvisäestyksellä. Sen jälkeen torvisoittokunnat esittivät Sivorin johdolla virret Jumala ompi linnamme ja Kiitos ja kunnia Herralle. Välissä myytiin arpoja Itä-Karjalan kansanopiston hyväksi, lausuttiin Alpo Noposen juhlaa varten sepittämä Suviruno ja kuultiin Siegbergin johtamaa mieskuoron esittäminä kappaleet Suomenkin maass', Oi terve Pohjola, Faltinin sovittama Kun ystävä jätti ja Reissingerin Jos minne kuljen. Puheissa toistettiin laulu- ja soittojuhlien merkitystä "mielen jalojen aatteiden" kohottajana. Puheiden jälkeen laulettiin yhteisesti Maamme torvien säestyksellä ja huudettiin "eläköön isänmaalle". Juhlan lopuksi esitettiin vielä laulunäytelmä Saimaan rannalla. Sitä odotellessa lauloivat useat yksityiset laulukuorot. Illan kuluessa luettiin myös onnittelusähkeitä, joita oli saapunut muun muassa Satakunnan laulu- ja soittojuhlan juhlatoimikunnalta sekä runoilija J. H. Erkolta, joka oleskeli juhlan aikaan Sveitsissä. (Laatokka 25.6.1898; Wiipurin Sanomat 26.6.1898; Mikkeli 1.7.1898.)

Toinen juhlapäivä aloitettiin laulu- ja soittokuntien kulkueella juhlapaikalle Kirvun lauluseuran johdolla. Juhlakentällä Kirvun lauluseura esitti virren $Y k s^{\prime}$ on Jumalamme. Sitä seurasi puhe, jonka jälkeen oli vuorossa laulu- ja soittokilpailut. Kilpakappaleina sekakuoroille olivat Boreniuksen On lintu liverrellyt sekä kansanlaulu Aamulla varhain, mieskuoroille Sivorin sovittama kansanlaulu Ja liekkö Luoja luonunna sekä Kaiu soitto. Torvisoittokunnat soittivat E. Pahlmanin Suomalaisia säveleitä sekä Laakson ruusun. Tuomaristo kiitti kilpailun tasoa hyväksi, joskin Laatokan toimittajan mukaan osa kilpailijoista olisi voinut harjoitella vielä ahkerammin (Laatokka 29.6.1898). Tuomariston mukaan juhlan paikallisesta luonteesta huolimatta "ovat kumminkin esitykset olleet parempia kuin useissa suuremmissakin laulujuhlissa". Huoposen, Sivorin ja Siegbergin lisäksi tuomaristoon valikoituivat vielä lehtori Eero Mäkinen Sortavalasta, Mooses Putro Pietarista, kuvataiteilija O. Kruskopf Valkjärveltä sekä kanttori K. H. Teittinen Sortavalasta. (Laatokka 29.6.1898; Wiipurin Sanomat 27.6.1898.)

Iltapäivällä oli vielä vuorossa kansanjuhla, jonka aikana kuultiin jälleen monia lauluja ja puheita. Musiikkiohjelmistoon kuuluivat muun muassa Kirvun lau- 


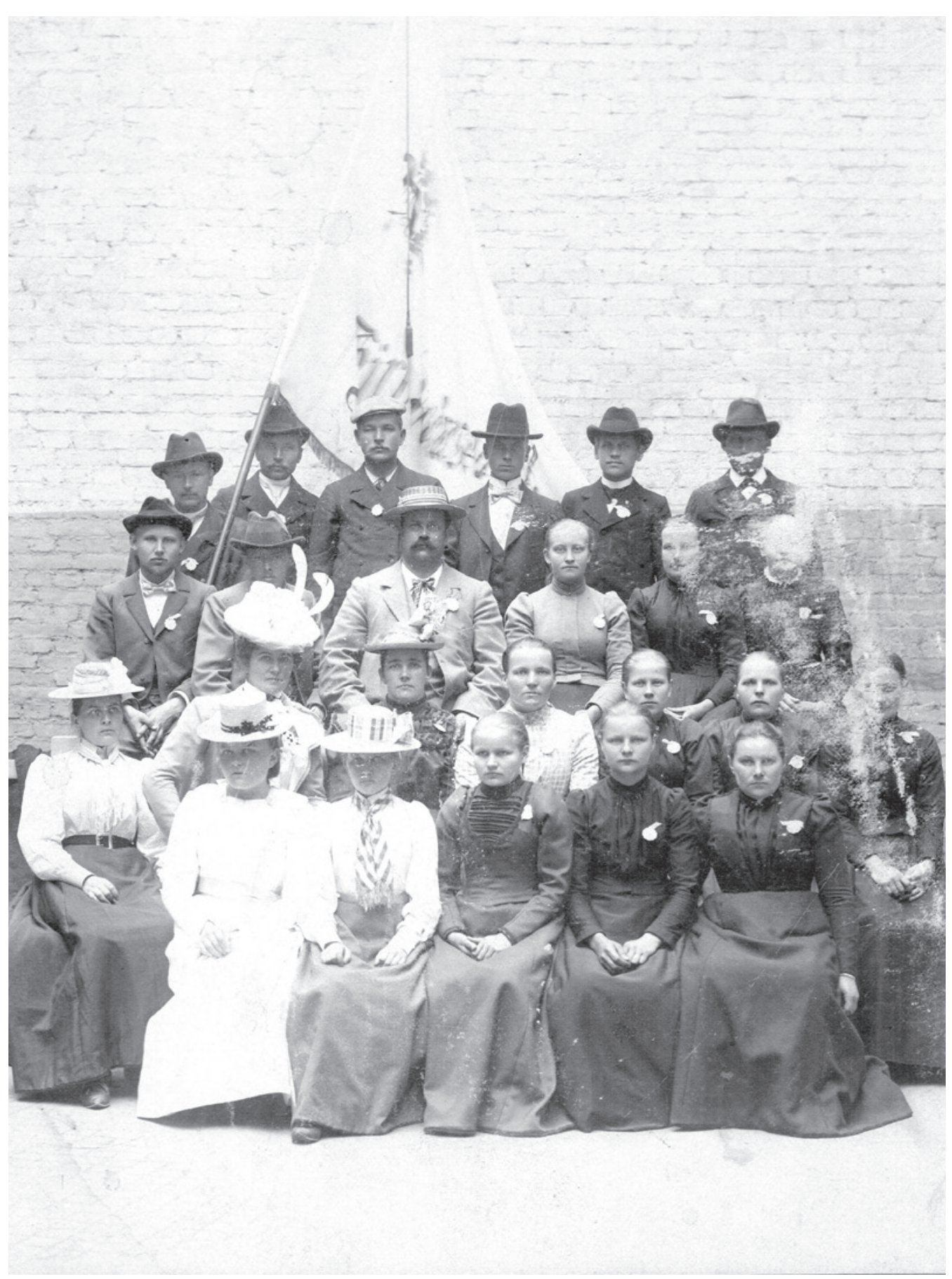

Kirvun lauluseura Helsingin laulu- ja soittojuhlassa 1900. Toiseksi ylimmässä rivissä kolmantena vasemmalla Nestor Huoponen vaaleassa asussaan. Kuva kirjoittajan hallussa. 
luseuran esittämät Valtaherra maan ja taivaan, Tuuti lasta Tuonelahan sekä Kuullos Suomi, jonka jälkeen Karjalan Lukkarikööri esitti Sivorin johdolla laulut Suomi armas synnyinmaamme, Tuomi on virran reunalla, Kyynel vuotaa silmistäni ja "yleisön hurratessa" Suomen laulun. Lukkariköörin jälkeen esiintyi vielä Mooses Putron johdolla inkeriläinen Keltun kuoro, joka lauloi Nouse Inkeri ja Savolaisen laulun. Viimeisenä oli vuorossa yksiäänistä laulua ja palkintojen jako. Laulujuhla lopetettiin laulamalla yhdessä torvien säestyksellä Oi Herra siunaa Suomen kansa sekä Maamme. Kansanjuhlaa koskevissa sanomalehtien juhlaselostuksissa ylistettiin Kirvun lauluseuraa ja etenkin Huoposen johtajantaitoja. Hänen avullaan kuoron ennustettiin voivan kehittyä "vaikka kuinka korkealle kehitysasteelle". Huoposta kiitettiin "juhlan oikeana sieluna". (Laatokka 29.6.1898.)

Lisänäkyvyyttä juhlalle toivat sen yhteydessä järjestetty nuorisoseurojen keskustelukokous sekä Karjalan lukkari-urkurien kokous, jonka järjestelyistä vastasivat Sivori ja Huoponen. Etenkin nuorisoseurojen kokouksen sisällöstä uutisoitiin sanomalehdissä laajasti. Lisäksi heti laulujuhlan jälkeen Joensuussa alkoi Suomen 16. yleinen raittiuskokous, jonka yhteydessä laulujuhlaa myös mainostettiin. Raittiusväen toivottiin matkalla piipahtavan myös Kirvussa. Tapahtumat mainostivat toisiaan puolin ja toisin. (Laatokka 18.6.1898; Wiipurin Sanomat 3.6.1898.)

Nuorisoseuran keskustelukokouksen keskeisenä kysymyksenä oli, miten saataisiin laulajien ja soittajien osanotto mahdollisimman suureksi Helsingissä vuonna 1900 pidettävään laulujuhlaan. Keskustelun lähtökohtana oli musiikkiosastojen lukumäärän lisääminen maaseutupaikkakunnille Helsingin juhlaa ajatellen. Helsingin laulujuhla oli valtava hanke, jota alettiin suunnitella jo 189o-luvun puolivälissä. Juhlasta ilmoitettiin aikaisin, jotta maaseudun laulu- ja soittokunnilla olisi tarpeeksi aikaa harjoitella ja valmistautua tärkeään tapahtumaan. Tarkoituksena oli järjestää "oikea vuosisatais-laulujuhla", jossa musiikki- ja sivistysharrastusten tila Suomessa saavuttaisi huippunsa. Juhla oli tärkeä myös siksi, että se pidettiin pääkaupungissa Helsingissä, missä laulujuhlia ei vielä kertaakaan ollut järjestetty. Kirvussa myös Huoponen painotti, että pääkaupungissa järjestettävä laulujuhla oli tapahtuma, jossa mitattaisiin koko "Suomen musiikkielämän" kehitys. Osallistuminen oli erityisen tärkeää maaseutukuorojen ja soittokuntien näkyvyyden kannalta. Huoposen mukaan juhlan ohjelma olisi saatava mahdollisimman pian painetuksi, jotta harjoitteluun olisi riittävästi ai- 
kaa. Lisäksi maakunnissa olisi järjestettävä paikallisia laulujuhlia, joissa ohjelmisto koostuisi Helsingin laulujuhlan kappaleista. Maakuntajuhliin voitaisiin myös yhdistää arpajaisia, joiden tuotot käytettäisiin laulu- ja soittokuntien matkakustannuksiin. Muu kokous yhtyi Huoposen ehdotukseen ja asiasta päätettiin tehdä ehdotus Suomen Nuorison Liiton toimikunnalle. Lisäksi toivottiin vielä, että Kirvun juhlan kaltaisia maakuntajuhlia järjestettäisiin Suomessa vuosittain. (Huoponen 1901: 37, 55-59.)

\section{Musiikin ylirajaiset yhteydet}

Menneisyydestä on mahdotonta löytää aikaa, jolloin ihmiset eivät olisi liikkuneet eri kansallisuuksien ja kulttuurien välillä. Liikkeelle on ajanut toisaalta työ, kaupanteko, opiskelu tai sota - toisaalta seikkailunhalu, uteliaisuus ja toiveet paremmasta elämästä. 180o-luvulla maailma avautui yhä nopeammin liikkumisen helpottuessa ja kulkuyhteyksien parantuessa. Suomessa nopea väestönkasvu, teollistuminen ja kaupungistuminen käynnistivät 1870-luvulta lähtien laajan muuttoliikkeen, joka muutti suomalaista yhteiskuntaa perinpohjin. Ihmiset muuttivat paikkakunnalta toiselle, toisenlaiseen elinympäristöön, jopa kokonaan toisenlaiseen yhteiskuntaan. Sen myötä muuttuivat myös ihmisten toiminta- ja ajattelumallit. Yleisin syy muuttamiselle oli työ, jonka vuoksi oltiin valmiita lähtemään myös oman maan rajojen ulkopuolelle. Yleisimmät kohteet olivat Pohjois-Amerikka ja Pietari. Muuttoliikkeen aiheuttama käänne ihmisten arjessa heijasteli samaa muutosta, mikä samanaikaisesti tapahtui valtion ja aatteiden tasolla. (Haapala 2007: 47-50.)

180o-luku oli hyvin kansainvälistä aikaa Suomessa. Osana monikulttuurista ja -kansallista imperiumia sekä kahden keskeisen suurkaupungin, Tukholman ja Pietarin, välissä Suomi houkutteli muusikoita ja muuta kulttuuriväkeä muualta Euroopasta. Rautateiden lisäksi höyrylaivaliikenteen aloittaminen Itämerellä 1830-luvun lopulla asetti Suomen rannikkokaupungit kiertävien muusikoiden kulkureiteille heidän matkustaessaan Itämeren alueella kaupungista toiseen (ks. Ollila 2014: 170-171). Muusikot ovat hyvin tyypillinen esimerkki työn vuoksi matkustavasta ammattiryhmästä. Muusikot ovat liikkuneet aina. Heidän mukanaan kulki luonnollisesti myös musiikki. Modernisaation myötä maailmankan- 
salaisuus, monikulttuurisuus ja kansainvälisyys haastoivat rakenteilla olevien kansalaisyhteiskuntien periaatteet paikallisesta identiteetistä ja kansallisesta homogeenisuudesta. (Ollila \& Saarelainen 2014: 10-13, 22.) Ne eivät kuitenkaan olleet ristiriidassa keskenään, sillä kansallisvaltiot ja -yhteiskunnat ovat aina myös yli- ja poikkikansallisia rakennelmia (Kettunen 2008: 17).

Suomikuvan keskeinen arkkitehti Zachris Topelius (1818-1898) luonnehti Ruotsin vallan kautta Suomen historiassa aikakaudeksi, jolloin suomalaiset olivat kohonneet eurooppalaisen sivistyksen piiriin omaksumalla länsimaisen arvomaailman ja keskeiset instituutiot, kuten kristinuskon, länsimaisen oikeusjärjestelmän ja kansakoulun. Topeliuksen mukaan Venäjän suunta oli Suomen tulevaisuutta ajatellen taantumuksellinen ja vieras. Sen vuoksi vuosi 1809 tarjosi suomalaisille mahdollisuuden luoda omaa historiaa ja kohottaa kansallista tietoisuuttaan autonomisena suuriruhtinaskuntana. (Ahtiainen \& Tervonen 1996: 34-42.)

Pääpiirteissään Topeliuksen ajatukset olivat peräisin saksalaiselta Johann Gottfried von Herderiltä, jonka käsitykset kielestä, kirjallisuudesta, kansasta ja kansakunnasta loivat käsitteellisen ja näkemyksellisen pohjan modernin kansallisvaltion kulttuurille. 180o-luvulla suomalaista identiteettiä ehkä voimakkaimmin muokanneen Maamme kirjan sivuilla Topelius nosti esille suomalaisuuden keskeisimmät osa-alueet, joita olivat maa ja maisema, kansanluonne, kieli, uskonto, kansanrunous ja historia. Näiden lisäksi tärkeässä roolissa olivat kansalaisten välinen tasa-arvo sekä omaleimainen kulttuuri, jossa suomalaisen kansakunnan ominaisluonne ja sivistys saavuttivat huippunsa. Topelius painotti erityisesti laulun ja kuvataiteen asemaa suomalaisuuden ilmentäjinä. (Mikkola 2006: 414-425. Topeliuksen maantieteenkäsityksestä ks. myös Tiitta 1994.)

Suomalaista kansakuntaa luotiin suhteessa eurooppalaisuuteen. Suomenkielisten aikalaishistorioitsijoiden mukaan kansallisella kulttuurilla ei voinut olla tulevaisuutta ilman yhteyksiä vuosisatoja vanhaan eurooppalaiseen sivistykseen, jonka se saattoi sulattaa omiin kansallisiin muotoihinsa sopivaksi. Kehittyäkseen Suomi tarvitsi itseään suurempien valtakuntien henkisiä ja aineellisia voimavaroja. Toisaalta jos Suomen kansalta puuttui omintakeinen ja vahva kulttuuria luova kyky, sen sivistyselämä tukahtuisi helposti eurooppalaisen vaikutuksen alle. Oli tehtävä kompromissi, joka takaisi Suomelle mahdollisuuden tasavertaiseen kanssakäymiseen muiden Euroopan valtioiden kanssa. Eurooppalaisuudessa oli kyse vuorovaikutuksesta, jossa kunkin kansakunnan velvollisuuksiin kuului an- 
taa oma panoksensa maanosan kulttuurikehitykselle. Tätä omaleimaista panosta tuli hakea kansasta, jonka olemusta niin tieteen kuin taiteenkin oli etsittävä ja esiteltävä kaikilla niillä metodeilla ja keinoilla, jotka luontuivat tähän tarkoitukseen. (Ahtiainen \& Tervonen 1996: 61; ks. myös Ollitervo \& Immonen 2006: 8-9.) Laulu- ja soittojuhlat lieveilmiöineen oli yksi näistä keinoista. Samalla ne ovat kuvaava esimerkki siitä, kuinka Suomi asukkaineen oli kiinteä osa eurooppalaista kulttuurista ja poliittista toimintakenttää.

Vaikka laulu- ja soittojuhlilla oli Suomessa hyvin kansallinen leima, sanomalehtiä lukevalle ja juhlille osallistuvalle kansalle ei jäänyt epäselväksi, että esikuvat laulujuhlien kaltaisille uusille ilmiöille tulivat Suomen rajojen ulkopuolelta. Sanomalehdet olivat suomalaisille portti ulkomaailmaan. Kotimaan uutisten lisäksi 180o-luvun puolivälin jälkeen lisääntyneissä suomenkielisissä sanomalehdissä uutisoitiin ahkerasti myös ulkomaan tapahtumia. Usein lehdissä oli kokonaan oma palsta kansainvälisille uutisille. Toimittajat käänsivät ja referoivat ulkomaisissa lehdissä julkaistuja aineistoja suomenkielelle, jonka jälkeen uutiset kiersivät sanomalehdestä toiseen. (Ollila 2014: 170.) Lehtiuutiset toivat palan eurooppalaista musiikkikulttuuria ihmisten koteihin. Tärkeitä uutisaiheita olivat esimerkiksi suomalaisten laulajattarien ja muiden taiteilijoiden menestys ulkomailla. Toimittajat korostivat heidän merkitystään Suomen edustajina Euroopassa, vaikka taiteilijat itse saattoivat olla asiasta toista mieltä. Monet heistä olivat kosmopoliitteja taiteilijoita, jotka tekivät kansainvälistä uraa osana ylirajaista taiteilijayhteisöä ilman kansallista agendaa (Kurkela 2014: 21).

Laulu- ja soittojuhlien malli tuli Suomeen Virosta ja Saksasta. Virosta vaikutteet kulkeutuivat Suomeen yksityishenkilöiden välityksellä. (Ks. Zetterberg 1974; Smeds \& Mäkinen 1984.) Sanomalehtien laulujuhlauutisoinnissa Viron esimerkkiä korostettiin usein. Myös Kirvussa Viro laulujuhlaliikkeen esikuvana nousi esille nuorisoseurojen yleisessä keskustelussa paikallisten laulu- ja soittojuhlien tulevaisuudesta. Keskustelun alusti Huoponen, joka huomautti, etteivät tähän saakka järjestetyt laulujuhlat Suomessa olleet vielä täyttäneet tarkoitustaan. Hänen mielestään "olisi pyrittävä niin pitkälle kuin veljeskansamme virolaiset, joiden laulujuhlat ovat suuremmoisia". Huoponen oli hyvin perillä Viron juhlien taustoista ja laulujuhla-aatteen kulkeutumisesta Suomeen. Hän kirjoitti Viron mallista myös muistelmissaan. Tiettävästi hän ei kuitenkaan itse vieraillut Viron laulujuhlilla. (Huoponen 1901: 57.) 
Sekä valtakunnalliset että niiden myötä paikalliset laulujuhlat kopioivat rakenteensa ja sisältönsä yksityiskohtaisesti eurooppalaisten mallien mukaan. Ensimmäiset kokonaan kuorolaulun ja ympärille järjestetyt musiikkijuhlat järjestettiin Saksassa 1810-luvulla. Juhlat sisälsivät myös kansallisia sävyjä. Varsinainen eurooppalaisen kuorofestivaaliliikkeen liikkeellepaneva voima oli kuitenkin saksalaisen Deutsche Sängerbund -yhdistyksen perustaminen vuonna 1862. Se oli eräänlainen keskusjärjestö, jonka tehtävänä oli paikallisten kuorojen yhteistoiminnan lisääminen. Pian perustamisensa jälkeen sen yhteyteen alettiin järjestää valtakunnallista musiikkifestivaalia, jonka perimmäisenä tarkoituksena oli voimistaa ajatusta yhtenäisestä Saksasta. Festivaaliliikkeen sielu oli sekaääniset, järjestäytyneet kuorot, jotka toimivat yhdistysten tavoin. Malli levisi nopeasti muualle Eurooppaan. Tehokkaimmin sitä levittivät kiertävät tai opiskelun vuoksi ulkomailla oleskelevat muusikot sekä kuorot, jotka esiintymismatkoillaan tekivät laulu- ja festivaaliaatetta tutuksi kotimaassaan ja ulkomailla. Musiikkifestivaalien myötä myös osallistujien maantieteellinen tietoisuus kasvoi, kun sanomalehtien palstoilla tai koulun penkillä etäisesti tutuiksi tulleet paikkakunnat, kaupungit tai kokonaan uudet valtiot saivat konkreettisen muodon esiintymismatkojen yhteydessä: kuvitellut yhteisöt tulivat näkyviksi. (Appelgate 2013: 9-10. Kuviteltujen yhteisöjen käsitteestä ks. Anderson 2007.)

Myös festivaalien musiikkiohjelmistot olivat samankaltaisia ympäri Eurooppaa. Niiden perustana oli yleiseurooppalainen taidemusiikki, jonka keskiössä olivat klassismin aikakauden mestarit Haydn, Beethoven ja Mozart (Kurkela 2014: 19). Eurooppalaisen sivistyneistön piirissä 180o-luvulla klassisen musiikin kaanonin universaalia asemaa perusteltiin musiikillisten syiden lisäksi myös sen henkisillä vaikutuksilla. Saksalaisen filosofin Wilhelm von Humboldtin (1767-1835) mukaan kaanon oli eräänlainen ideologia, joka ilmensi monia humanistisia arvoja, kuten avarakatseisuutta ja vapautta. Sillä oli myös monia eheyttäviä sosiaalisia ja fyysisiä vaikutuksia. Lisäksi klassismin kaanon oli ylirajaisen kommunikaation väline, "kansainvälinen kieli", jonka avulla oli mahdollista ylittää eri kansallisuuksien rajoja. (Gienow-Hecht 2009: 65; ks. myös Weber 2011: 211-212.) Myös populaarimusiikki kuului vielä tässä vaiheessa kiinteänä osana mannermaiseen repertuaariin. Populaarikonsertit koostuivat tavallisesti "helposti sulatettavista" lyhyemmistä kappaleista, kuten ooppera-aarioista, sinfonisista runoista, sonaateista, huilu-, piano- tai viulusooloista sekä marssi- ja 
tanssimusiikista. Kevyt ja vakava musiikki vuorottelivat festivaalien ja konserttien ohjelmistoissa.

Musiikki ei siirtynyt Suomeen sellaisenaan, vaan sitä muokattiin Suomen oloihin ja tavoitteisiin sopivaksi. Erityisesti paikallisilla laulujuhlilla instrumentaalimusiikki oli vähemmistössä. Laulujen sanat olivat sävelmiä tärkeämmät, sillä niiden avulla tapahtumien tavoitteet konkretisoituivat yleisölle tehokkaammin. Kirvun juhlaohjelma on tästä hyvin kuvaava esimerkki. Musiikkiohjelmisto koostui virsistä, kansanlauluista ja isänmaallisista lauluista, joissa korostuivat edellä mainitut kansallisvaltion rakentamiseen liitetyt keskeiset teemat. Sama käytäntö toistui myös valtakunnallisilla juhlilla, mutta sillä erotuksella, että niiden ohjelmistoihin sisältyi tavallisesti haastavampiakin taidemusiikkikonsertteja. Erityisen kuvaavan esimerkin taidemusiikin asemasta suhteessa rahvaan omaan musiikkikulttuuriin antoi Jyränkö-lehti referoidessaan Helsingin laulujuhlien musiikkiohjelmaa. Toimittaja oli vakuuttunut taidemusiikin asemasta musiikkikulttuurin huipulla. Samalla jutusta välittyy musiikin ylirajainen luonne, jota kirjoittaja ei pyri millään tavalla peittelemään. Hän nostaa esille myös Suomen musiikkielämän kehityksen kannalta keskeisiä vaikuttajia:

Historiallisissa konserteissa valmistetaan yleisölle tilaisuus seuraamaan askel askeleelta suomalaisen laulun ja soiton kehitystä aina Väinämöisen kanteleesta ja runonlaulajain yksinkertaisesta säveleestä nykyiseen taidemusiikkiin saakka, jota meillä edustavat nimet sellaiset kuin Sibelius, Kajanus ym. - - Orkesterikonserteissa esittää filharmonisen seuran orkesteri suurten sivistysmaiden vanhemman ja uudemman musiikkikirjallisuuden parhaita teoksia. (Jyränkö 15.5.1900.)

Suomeen uudet keskieurooppalaiset musiikkivaikutteet kulkeutuivat maassa oleskelevan ulkomaisen muusikkokunnan, musiikkikauppiaiden sekä ulkomaille opiskelemaan lähteneiden ja sieltä palanneiden musiikkielämän auktoriteettien välityksellä. Koska Suomi oli pieni maa, ja suomalainen kansallisidentiteetti ja kansallisvaltio olivat vasta muotoutumassa, yksittäisten aktiivisten toimijoiden rooli korostui suhteessa maan musiikkikulttuurin kehittymiseen (Kurkela 2014: 21). Vuosina 1856-1900 kaikkiaan 44 suomalaista tai suomessa vaikuttanutta muusikkoa opiskeli Leipzigin konservatoriossa, mikä kuului eurooppalaisten musiikkioppilaitosten parhaimmistoon. Heidän joukossaan olivat myös 
suomalaisten laulu- ja soittojuhlien keskeiset vaikuttajat, kuten Richard Faltin, Robert Kajanus, Martin Wegelius, Oskar Merikanto, Ilmari Krohn ja Emil Sivori, joista Merikanto ja Sivori toimivat aktiivisesti myös paikallisilla laulujuhlilla. 1880-luvulta lähtien myös Berliini, Wien ja myöhemmin Pariisi olivat suosittuja opiskelukaupunkeja. Suomalaisten muusikoiden verkostoja eurooppalaisiin laulujuhliin ei ole tähän mennessä vielä tutkittu, mutta on hyvin todennäköistä, että monet heistä tutustuivat opiskeluaikanaan saksalaiseen laulujuhlainstituutioon ja mahdollisesti myös osallistuivat tapahtumiin.

\section{Idän ja lännen risteyksessä}

Suomi ei ollut ylirajaisissa yhteyksissään ainoastaan vastaanottajan roolissa, vaan myös Suomesta haettiin vaikutteita muualta. Yksi esimerkki käänteisestä liikkeestä liittyy Kirvun laulu- ja soittojuhlaan osallistuneen inkeriläisen Keltun mieskuoron vierailuun ja sen jälkeisiin tapahtumiin. Päivälehden mukaan yleisön joukossa oli suomalaisten lisäksi "paljon" osallistujia Virosta ja Inkerin puolelta. (Päivälehti 28.6.1898.) Lukumäärää ei määritellä tarkemmin, mutta etenkin inkeriläiset saivat sekä juhlassa että sanomalehdissä runsaasti huomiota. Lehtikirjoittelun perusteella Keltun kuoro teki juhlayleisöön ja järjestäjiin suuren vaikutuksen. Kuoro sai hyvät arviot esiintymisistään. Kilpailun lisäksi kuoroa kuultiin laulujuhlan yhteydessä järjestetyssä kansanjuhlassa sekä muualla juhla-alueella. Arvostuksesta kertoo myös se, että inkeriläiset nostettiin esille kansanjuhlan yhteydessä pidetyssä loppupuheessa. (Laatokka 4.7.1898.) Räisälän kirkkoherra Elis Bergroth kiitti inkeriläisiä vierailusta ja toivotti heille onnea sivistyspyrinnöissään. Inkeriläinen opettaja P. Räikkönen vastasi puheeseen kiittäen järjestäjiä inkeriläisten puolesta ja kertoi, kuinka Suomen "henkiset riennot ovat ulottuneet Rajajoen toiselle puolelle saakka". Hän kuvaili puheessaan Inkerinmaan "kovia oloja" ja puhui heidän valistusharrastuksistaan. (Wiipurin Sanomat 28.6.1898.)

Inkeriläisillä oli tiiviit yhteydet Suomeen. Koko 180o-luvun ajan etenkin ItäSuomesta muutettiin tasaisena virtana Venäjälle: Karjalaan, Inkerinmaalle ja Pietariin. Autonomian vuosina 1809-1917 raja Karjalan kannakselta Pietariin oli auki, ja rajan yli kulki jopa tuhansia ihmisiä päivässä. Suomalaisia vei itään työ- ja 
kauppamatkat. Pietari ja sen lähialueet olivat riippuvaisia suomalaisista elintarvikkeista, haloista ja kivistä. Siitä huolimatta, että Suomi oli osa Venäjän keisarikuntaa, maiden välillä oli tulli- ja passiraja. Suomalaisilla oli oma kansallisuus ja siinä mielessä oltiin todella "ulkomailla". Muuttoliikkeen seurauksena moni jäi Venäjälle pysyvästi. 1880-luvulla Pietarissa oli jo niin paljon suomalaisia, että sitä sanottiin "Suomen toiseksi suurimmaksi kaupungiksi". Suomalaisuus näkyi kaupungissa monin tavoin. Sinne syntyi muun muassa oma suomalaisyhteisö, jonka jäsenet kävivät suomalaista koulua ja perustivat kaupunkiin monia suomalaisia yhdistyksiä, kuoroja ja muuta seuratoimintaa. Vaikutteet suomalaisten ja venäläisten välillä kulkivat vilkkaasti puolin ja toisin. Inkeriläisiä ja suomalaisia yhdisti myös kieli ja uskonto, sillä Inkerinmaalla valtaosa asukkaista olivat luterilaisia ja puhuivat Suomea. Siitä johtuen Inkerissä tunnettiin voimakkaampaa heimoyhteyttä suomalaisia kuin venäläisiä kohtaan. (Haapala 2007: 55-56.)

Vain muutama viikko Kirvun laulujuhlan jälkeen inkeriläisten mukana ollut kuoronjohtaja ja Pietarin Pyhän Marian kirkon urkuri Mooses Putro (1848-1918) kirjoitti Inkeri-lehteen inkeriläisten pyrkimyksistä järjestää oma laulu- ja soittojuhla Kirvun mallin mukaan jo seuraavana kesänä. Putro oli keskeinen henkilö Inkerin ja Pietarin musiikkielämässä. Hän on myös laulun Nouse Inkeri säveltäjä ja ensimmäisen säkeistön sanoittaja. ${ }^{5}$

Lehtijutussaan Putro ideoi juhlan ohjelmaa. Tärkeässä roolissa olisi yksiääninen laulu, jota hän kehotti kaikkia opettajia ja lukkareita alkaa välittömästi harjoittaa. Koska juhlaan kuitenkin osallistuisi myös jo olemassa olevia kuoroja, kuten Keltun kuoro ja Pietarin Suomalainen lauluseura, olisi juhlassa hyvä olla oma osuutensa myös moniääniselle laululle. Kuorojen vähyydestä johtuen hän suositteli, ettei kilpailuja järjestettäisi vielä ensimmäisellä kerralla. Lisäksi juhla kestäisi vain yhden päivän. (Wiipurin Sanomat 10.7.1898.)

Syyskuussa Wiipurin Sanomat (4.9.1898) uutisoi, että Inkerin raittiusyhdistys on ottanut seuraavaksi kesäksi suunnitellun laulujuhlan järjestelyt vastuulleen. Samassa kokouksessa oli perustettu myös tarvittavat toimikunnat. Juhla pidettäisiin raittiusseuran vuosijuhlan yhteydessä Skuoritsassa. (Wiipurin Sanomat 15.10.1898.) Kuukauden kuluttua julkistettiin myös juhlan musiikkioh-

5 Mooses Putro tunnetaan myös siitä, että hän oli mukana ensimmäisten kotimaisiksi laskettavien äänitteiden teossa vuonna 1901, kun Gramophone Company tallensi Putron johtaman Pietarin suomalaisen lauluseuran esityksiä Pietarissa (http:/ / www.inkeri.com/Virtuaali/M_Putro.htm). 
jelma, joka esikuviensa mukaisesti sisälsi suomalaisia kansanlauluja, virsiä ja isänmaallisia lauluja. Suurin osa kappaleista kopioitiin suoraan Kansanvalistusseuran laulukirjoista. (Wiipurin Sanomat 31.10.1898.) Loppuvuodesta 1898 juhlajärjestelyt olivat vähällä keskeytyä kirkkoherran ja viranomaisten vastustukseen, mutta lopulta ne kuitenkin järjestettiin. Juhla onnistui hyvin. Päivälehden (27.6.1899) mukaan osallistujia oli yhteensä noin 2000 henkeä, joista peräti 500 laulajia. Juhlaohjelmassa oli myös torvisoittoa, mutta huomattavasti vähemmän kuin Suomen juhlilla. Syynä soittokuntien vähäiseen näkyvyyteen oli mitä todennäköisimmin niiden puute. Putron johdolla Inkerin laulujuhlia järjestettiin vuodesta 1899 lähtien Venäjän vallankumoukseen ja Putron kuolemaan (1918) saakka. Inkerin juhlan aikaan myös Pietariin suunniteltiin suomalaista laulujuhlaa, mutta siitä ei löydy mainintoja seuraavan vuoden sanomalehdistä (Uusimaa 7.10.1898).

Toinen kiinnostava ylirajaisten verkostojen suunta Suomesta oli Amerikka, johon Suomesta suuntautui valtava kansainvaellus 1800-luvun lopulla. 1890-luvulla kaikkiaan 55 ooo suomalaista hankki passin matkustaakseen Amerikkaan. Lähtijöiden lukumäärää kuvastaa hyvin se, että 1900-luvun alussa siirtolaisuus ylitti kotimaisiin kaupunkeihin suuntautuneen muuttoliikkeen. Useimmat lähtijöistä olivat maaseudulta tulleita 15-25-vuotiaita perheettömiä nuoria miehiä, jotka liikkeelle saivat kato- ja lamavuodet sekä Venäjän armeijan kutsunnat. Siirtolaisia lähti eniten Pohjanmaalta, missä väestönkasvu oli nopeinta ja teollisuutta vähän. (Haapala 2007: 53-55; Kero 1997: 13-16.)

Kirvun juhla ajoittui siirtolaisuuden vilkkaimpaan vaiheeseen. Saman vuoden aikana sanomalehdissä alettiin julkaista Amerikan suomalaisten siirtolaisten kirjoituksia liittyen Helsingin suurlaulujuhliin vuosisadan vaihteessa. Kesällä 1898 Amerikassa ilmestyneen sanomalehden Amerikan Suomalaisen kirjeenvaihtaja välitti Suomeen uutissähkeen, jossa ilmaistiin siirtolaisten suunnitelmista koota keskuudestaan kuoro ja osallistua laulujuhlaan. Juhlan ajankohta oli lähekkäin Pariisissa järjestettävän maailmannäyttelyn kanssa, johon laulajat suunnittelivat myös osallistuvansa. Uutinen julkaistiin useassa suomalaisessa sanomalehdessä. (Ks. esim. Uusimaa 26.7.1898; Mikkelin Sanomat 28.7.1898.) Siinä kerrottiin, että "yksityisissä piireissä on täällä [Amerikassa] herännyt ajatus muodostaa valiojoukko laulumiehiä laulukunnaksi, joka sitten liittyisi se suuren kansalaisjoukon etupäähän, joka vuonna 1900 lähtee Amerikasta Parisin maailmannäyttelyyn, 
poiketen samalla tiellään Suomessa". Samalla toivottiin, että heitä pidettäisiin ajan tasalla juhlaohjelmasta ja kilpakappaleista, jotta kuoro pääsisi harjoittelemaan ajoissa. Jutussa painotettiin siirtolaisten isänmaallisuutta Suomea kohtaan, jota etenkin fennomaanit epäilivät. Heidän näkökulmastaan siirtolaisuus oli vastoin kansallisvaltion periaatteita ja sen vuoksi siihen suhtauduttiin fennomaanien keskuudessa kielteisesti (ks. esim. Smeds 1993: 9).

Pietarin tavoin uudella mantereella suomalaisyhteisö oli hyvin tiivis ja yhteydenpito kotimaahan vilkasta. Yhteyksiä ylläpidettiin etenkin sanomalehtien ja kirjeenvaihdon välityksellä. 18oo-luvun loppu oli Suomessa vilkasta järjestäytymisen aikaa ja vaikutteet levisivät nopeasti myös Amerikkaan. Siirtolaisyhteisöissä perustettiin yhdistyksiä, soittokuntia, kuoroja ja näytelmäseuroja, jotka edistivät yhteisöllisyyttä siirtolaisten kesken. Myös omia sanomalehtiä perustettiin. Suomalaiset olivat muihin siirtolaisiin verrattuna poikkeuksellisen lukutaitoisia. Sen vuoksi heillä oli verrattain hyvät mahdollisuudet perustaa sanomalehtiä ja muuta kulttuuritoimintaa. Amerikan uutisten lisäksi amerikansuomalaisissa sanomalehdissä raportoitiin tarkasti Suomen asioita. Suosituimpia uutisia olivat kansankirjeet, joiden avulla siirtolaiset pystyivät seuraamaan mitä perheelle, sukulaisille ja muille tuttaville kuului. Vaikutteet liikkuivat myös toisin päin. Aktiivisen yhteydenpidon ohella noin kolmannes Amerikan siirtolaisista palasi takaisin Suomeen tuoden mukanaan erilaisia vaikutteita "suuresta maailmasta". (Ks. Kero 1997; Pollari 2012.)

Suomalaisten sanomalehtien Helsingin laulujuhlaan liittyvistä lukuisista tapahtumaselostuksista ei löydy mainintoja amerikansuomalaisten osallistumisesta juhlaan. Siirtolaisten keskuudessa ajatus laulu- ja soittojuhlista jäi kuitenkin kytemään. Ensimmäiset laulu- ja soittojuhlat Amerikan suomalaisyhteisössä järjestettiin todennäköisesti jo 189o-luvun lopulla. Varmaa on, että viimeistään vuosisadan vaihteen jälkeen laulu- ja soittojuhlat vakiintuivat osaksi siirtolaisten musiikkikulttuuria. Suomalaiset laulujuhlat eivät kuitenkaan olleet niiden ainoa malli, sillä Amerikassa esimerkiksi saksalaisyhteisön keskuudessa järjestettiin laulujuhlia, jotka toimivat esikuvina muille. Siirtolaisten mukana eurooppalainen musiikkikulttuuri rantautui 180o-luvun aikana voimakkaasti Amerikkaan (ks. Gienow-Hecht 2009). 


\section{Lopuksi}

Miten siis oli mahdollista, että pienen maaseutupaikkakunnan kuoro pystyi ottamaan laulujuhlan kaltaisen massatapahtuman järjestettäväkseen Suomessa 1890-luvun lopulla? Keskeisin tae lauluseuran onnistumiselle oli kuorolaisten tiivis yhteisöllisyys. Vaikka pääosin liikkuvasta nuorisosta koostuva kuoro kärsi toisinaan suhteellisen vilkkaasta vaihtuvuudesta, toiminnallisuuden säilymisen takasi kuitenkin kuoron suuri koko. Toiseksi osallistuminen Kansanvalistusseuran laulu- ja soittojuhlille lähes alusta alkaen antoi kuorolaisille tärkeän toimintamallin, joka periytyi laulajalta toiselle. Esiintymismatkat oman maakunnan ulkopuolelle toivat kokemusta ja itsevarmuutta ei ainoastaan esiintymiseen, vaan myös erilaisten tapahtumien organisoimiseen. 189o-luvun loppuun tultaessa kuorotoiminta oli Kirvussa vakiintunut ja tullut tutuksi sekä kuorolaisille että myös Kirvun asukkaille monien julkisten esiintymisien seurauksena. Lisäksi sanomalehdet ja pitäjään perustetut erilaiset yhdistykset tekivät järjestötoimintaa tutuksi iltamineen ja kesäjuhlineen.

Tärkeimmässä roolissa oli kuitenkin pitkäaikaisen johtajan Nestor Huoposen saavutukset. Hänen kokemuksensa ja verkostonsa takasivat sen, että järjestelyt sujuivat aikataulussa ja ammattitaidolla. Hän nautti kirvulaisten ehdotonta luottamusta, joka ei ollut himmentynyt vuosien saatossa. Huoposen vaikutuksesta juhlajärjestelyihin rekrytoitiin mukaan myös Emil Sivori ja Artur Siegberg, joiden yhteydet sekä ulkomaille että muuhun musiikkielämän Suomessa takasivat sen, että juhlaohjelma oli ajan tasalla yleisten virtausten kanssa. Sivorin ja Siegbergin musiikilliset ansiot asettivat heidät suomalaisten musiikkivaikuttajien eturiviin. Siegbergin toiminta Ylioppilaskunnan Laulajien ja Muntra Musikantenin riveissä sekä johtajana että laulajana toi hänelle valtavasti kokemusta, jonka hän mielellään jakoi kotipaikkakunnallaan. Siegbergin toiminnan tuloksena Kirvuun kulkeutui myös paljon ohjelmistoa, etenkin ylioppilaslauluja. Kuoron esiintymismatkoilla hän oli tärkeä tuki, sillä kotimaan lisäksi hänellä oli kokemusta konsertoinnista ulkomailla Muntra Musikantenin laulumatkoilla Pietarissa 1887 ja Pariisissa 1889. (Jyrkinen et al. 1993: 135-137, 167.)

Emil Sivori oli ollut mukana jo Hiitolan kokouksessa valitsemassa Kirvun lauluseuraa laulujuhlan johtoon. Sivori ja Huoponen olivat molemmat Turun lukkari-urkurikoulun kasvatteja. He eivät tiettävästi opiskelleet samaan aikaan 
vaan tutustuivat myöhemmin. Se oli helppoa, sillä Suomen musiikkipiirit olivat pienet ja lukkari-urkurien yhteisö tiivis. Huoponen valmistui Turusta vuonna 1879, Sivori seitsemän vuotta myöhemmin 1886, jonka jälkeen hän matkusti vielä Leipzigiin hankkimaan lisäoppia urkujensoitossa. Huoposen tavoin hän toimi aktiivisesti lukkari-urkurien hyväksi. Lisäksi Sortavalan ja myöhemmin Viipurin urkurina hänellä oli tärkeä merkitys Karjalan alueen musiikkielämän kehittymisessä. Sivori oli ollut mukana laulujuhlien järjestämisessä aikaisemminkin, edellisen kerran valtakunnallisessa laulujuhlassa Sortavalassa vuonna 1896. Lisäksi hän perusti useita kuoroja ja harrasti myös kansansävelmien keruuta. (Heikinheimo 1955: 690.) Myöhemmin niinikään lukkari-urkuripiireistä tuttu Oskar Merikanto osallistui Kirvun lauluseuran toimintaan säveltämällä laulukunnalle omistetun Laulajain marssin vuonna 1901. Sanat lauluun sepitti Alpo Noponen. Lukkari-urkurien toiminnan ohella Kirvun lauluseura oli Merikannolle tuttu Kansanvalistusseuran laulu- ja soittojuhlilta. (Ks. Ketomäki 2012: 100-101.) Tärkeä kontakti oli myös Mooses Putro.

Huoposen työura jatkui vuosisadan vaihteen jälkeen nousujohteisena. Vuosina 1899-1906 hänet valittiin talonpoikaissäädyn jäsenenä säätyvaltiopäiville. Monipuolinen ura huipentui vuonna 1907, kun hänet valittiin Suomen ensimmäiseen eduskuntaan, jossa hän toimi nuorsuomalaisten kansanedustajana vuoteen 1909 asti. Monista kiireistään huolimatta hän jatkoi Kirvun seurakunnan urkurina sekä lauluseuran johtajan tehtävissä kuolemaansa (1916) saakka.

Nuorisoseuraliikkeen piirissä laulu- ja soittojuhlista muodostui nopeasti vuotuinen traditio ja paikallisten musiikinharrastajien kohtaamispaikka. Kirvun juhla käynnisti varsinaisen paikallislaulujuhlabuumin, sillä lehtikirjoittelun perusteella heti seuraavaksi kesäksi niitä suunniteltiin ainakin Jyväskylään, Seinäjoelle, Lappeenrantaan, Kanneljärvelle, Uudellemaalle ja Turkuun. Myös ruotsinkieliset järjestivät omia laulujuhliaan, mutta niistä ei juurikaan kirjoitettu suomenkielisissä sanomalehdissä. Ruotsin- ja suomenkielisten juhlien ohjelmistot ja tavoitteet olivat kuitenkin hyvin samankaltaisia. Tämä välittyi hyvin esimerkiksi Tammisaaren ja Porvoon laulujuhlissa kesällä 1898. Suurimmat sisällölliset erot liittyivät kieleen. Kun suomenkieliset painottivat suomen kielen asemaa suomalaisen kansakunnan rakennusprosessissa, ruotsinkielisten tavoitteena oli säilyttää ruotsin kieli valtakielenä Suomessa. Ruotsinkielisten järjestämissä juhlissa välittyivät myös liberalistiset aatteet, joissa korostuivat läntisen sivistyksen merkitys Suomelle. 
180o-luvun lopulla laulu- ja soittojuhlat muodostivat Suomessa varsin laajan ja monisyisen paikallisten, kansallisten ja ylirajaisten vuorovaikutussuhteiden verkoston. Laulujuhlaliike ja siihen voimakkaasti kytkeytynyt yleiseurooppalainen musiikkikulttuuri olivat lähtökohtaisesti kansalliset rajat ylittävää toimintaa. Ylirajaisella vuorovaikutuksella oli voimakas vaikutus eri paikallisuuksissa toimivien, mutta samalla paitsi paikallisten, myös kansallisten ja kansainvälisten ajattelumallien yhteen sitomien ilmiöiden ja liikkeiden rakentamisessa. (Ks. Pollari 2012.) Laulujuhlat ovat tästä hyvin kuvaava esimerkki. Osallistumalla musiikkitoimintaan tai juhlajärjestelyihin, myös rahvaalla oli mahdollisuus kokea häivähdys kansallisvaltion rajat ylittävästä eurooppalaisesta kulttuuri-identiteetistä kansallisen ja paikallisen identiteetin rinnalla. 


\section{Lähdeluettelo}

\section{Arkistolähteet}

Kirvun lauluseuran arkisto. Virpi Kohon hallussa.

Hochschule für Music und Theater "Felix Mendelssohn Bartholdy" Leipzig, Bibliothek/Archiv.

\section{Sanoma- ja aikakauslehdet}

Jyränkö 1900

Laatokka 1898

Mikkeli 1898

Pyrkijä 1890-1900

Päivälehti 1898

Vaasan Sanomat 1898

Wiipurin Sanomat 1898

Wuoksi 1898

\section{Kirjallisuus}

Ahlquist, Karen (2006) Chorus and Community. Urbana and Chicago: University of Illinois Press. Ahtiainen, Pekka \& Tervonen, Jukka (1996) Menneisyyden tutkijat ja metodien vartijat. Matka suomalaiseen historiankirjoitukseen. Helsinki: Suomen Historiallinen Seura.

Anderson, Benedict (2007) Kuvitellut yhteisöt. Nationalismin alkuperän ja leviämisen tarkastelua. Suom. Joel Kuortti. Tampere: Vastapaino.

Applegate, Celia (2011) "Mendelssohn on the Road: Music, Travel, and the Anglo-German Symbiosis". New Cultural History of Music. Toim. Jane F. Fulcher. Oxford: University Press. Ss. 228-244. Applegate, Celia (2013) "The Building of Community Through Choral Singing ". Nineteenth Century Choral Music. Toim. Donna M. Di Grazia. New York and London: Routledge. Ss. 3-20. Gienow-Hecht, Jessica C. E. (2009) Sound Diplomacy. Music and Emotions in Transatlantic Relations, 1850-1920. Chicago and London: The University of Chicago Press. 
Haapala, Pertti (1997) "Kun kaikki alkoi liikkua...". Suomalaisen arjen historia 3. Modernin Suomen synty. Porvoo: wsoy. Ss. 47-63.

Heikinheimo, Ilmari (1955) Suomen elämäkerrasto. Helsinki: wsor.

Huoponen, N. E. (1901) "Kertomus Kirvun lauluseuran vaiheista 1881-1901". Kirvun lauluseura 1881-1944. Toim. Aune Jyrkinen, Väinö Jääskeläinen, Anni Koho \& Eeva Virolainen. Kirvu: Kirvun Lauluseura. Ss. 7-77.

Häyrynen, Antti (2008) Sinivalkoiset äänet. Ylioppilaskunnan laulajat 1883-2008. Helsinki: Otava. Inkilä, Arvo (1960) Kansavalistusseura Suomen vapaassa kansansivistystyössä. Helsinki: Otava.

Jyrkinen, Aune \& Jääskeläinen, Väinö \& Koho, Anni \& Virolainen, Eeva (1993) Kirvun lauluseura 1881-1944. Kirvu: Kirvun Lauluseura.

Jäppinen, Jere (2004) Osakunnan hauskin joukko: Hämäläis-Osakunnan laulajat 1929-2004. Helsinki: Hämäläis-osakunnan laulajat.

Kero, Reino (1997) Suomalaisina Pohjois-Amerikassa. Siirtolaiselämää Yhdysvalloissa ja Kanadassa. Turku: Siirtolaisuusinstituutti.

Ketomäki, Hannele (2012) Oskar Merikannon kansalliset aatteet. Merikannon musiikkijuhlatoiminta sekä ooppera Pohjan neiti ja kuorolaulut venäläistämiskauden laulu- ja soittojuhlien ohjelmissa. Helsinki: Sibelius-Akatemia.

Kettunen, Pauli (2008) Globalisaatio ja kansallinen me. Kansallisen katseen historiallinen kritiikki. Tampere: Vastapaino.

Kurkela, Vesa (1989) Musiikkifolklorismi \& järjestökulttuuri. Kansanmusiikin ideologinen ja taiteellinen hyödyntäminen suomalaisissa musiikki- ja nuorisojärjestöissä. Helsinki: Suomen Etnomusikologinen Seura.

Kurkela, Vesa (2014) "Universal, National or Germanised?". FMQ 2/1014, ss. 18-21.

Lehtonen, Eeva-Liisa (1994) Sä̈tyläishuveista kansanhuveiksi, kansanhuveista kansalaishuveiksi. Maaseudun yleishyödyllinen huvitoiminta 180o-luvun alusta 1870-luvun loppuun. Helsinki: Suomen Historiallinen Seura.

Mikkola, Kati (2006) "Suomen kehkeytyminen omaksi itsekseen". Herder, Suomi ja Eurooppa. Toim. Sakari Ollitervo \& Kari Immonen. Helsinki: Suomalaisen kirjallisuuden seura. Ss. 414-444. Ollila, Anne \& Saarelainen Juhana (toim.) (2014) Kosmopoliittisuus, monikulttuurisuus, kansainvälisyys. Kulttuurihistoriallisia näkökulmia. Turku: Turun yliopisto.

Ollila, Anne (2014) "Valokuvaus - moderni ja kansainvälinen ammatti 180o-luvun Suomessa". Kosmopoliittisuus, monikulttuurisuus, kansainvälisyys. Kulttuurihistoriallisia näkökulmia. Turku: Turun yliopisto. Ss. 168-193.

Ollitervo, Sakari \& Immonen, Kari (2006) Herder, Suomi ja Eurooppa. Helsinki: Suomalaisen kirjallisuuden seura. 
Pajamo, Reijo (1976) Suomen kansakoulujen laulunopetus vuosina 1843-1881. Helsinki: Suomen musiikkitieteellinen seura.

Pollari, Mikko (2012) "Teosofia ja 1900-luvun alun suomalaisen ja amerikansuomalaisen työväenliikkeen transatlanttiset yhteydet". Työväki maahanmuuttajana. Toim. Sakari Saaritsa \& Kirsi Hänninen. Väki voimakas 25. Helsinki: Työväen Historian ja Perinteen Tutkimuksen Seura. Ss. 46-69.

Rantanen, Saijaleena (2013a) "Laulu- ja soittojuhlat suomalaisen kansakunnan rakentajina 180o-luvun lopulla". Musiikki 3-4/2013, ss. 61-84.

Rantanen, Saijaleena (2013b) Laulun mahti ja sivistynyt kansalainen. Musiikki ja kansanvalistus EteläPohjanmaalla 1860-luvulta suurlakkoon. Helsinki: Sibelius-Akatemia.

Saarnio, A. H. (1901) "Taloudellinen asema". Kirvun lauluseura 1881-1944. Toim. Aune Jyrkinen, Väinö Jääskeläinen, Anni Koho \& Eeva Virolainen. Kirvu: Kirvun Lauluseura. Ss. 124-125. Siikaniemi, Alku (1901) "Jyväskylässä käynti 1887." Kirvun lauluseura 1881-1944. Toim. Aune Jyrkinen, Väinö Jääskeläinen, Anni Koho \& Eeva Virolainen. Kirvu: Kirvun Lauluseura. Ss. 94-105.

Smeds, Kerstin \& Mäkinen, Timo (1984) Kaiu, kaiu lauluni. Laulu- ja soittojuhlien historia. Helsinki: Otava.

Smeds, Kerstin (1993) "The Image of Finland at the World Exhibitions 1900-1992". The Finland Pavilions at the Universal Expositions 1900-1992. Toim. Peter B. MacKeith \& Kerstin Smeds. Tampere: Tammer-Paino Oy. Ss. 14-23.

Suomen tilastollinen vuosikirja 1940. Helsinki: Tilastollinen päätoimisto.

Sutinen, R. (1971) "Kirvun nuorisoseurat toimivat vireästi." Karjalan lehti 13/1971. Ss. 4-5.

Särkkä, Irma-Liisa (1973) Laulu- ja soittojuhlat Suomessa autonomian aikana v. 1881-1917. Jyväskylä: Jyväskylän yliopisto.

Tiitta, Allan (1994) Harmaakiven maa. Zacharias Topelius ja Suomen maantiede. Helsinki: Suomen Tiedeseura.

Vertovec, Steven (2009) Transnationalism. London and New York: Routledge.

Weber, William (2011) "Cosmopolitan, National, and Regional Identities in Eighteenth-Century European Musical Life". New Cultural History of Music. Toim. Jane F. Fulcher. Oxford: University Press. Ss. 209-227.

Ylönen, Aulikki (1954) Kirvun kirja. Helsinki: Helisevä-säätiö.

Zetterberg, Seppo (1974) Suomi ja Viron ensimmäiset yleiset laulujuhlat. Historiallinen Aikakauskirja 4/1974: 281-297. 